Historic, archived document

Do not assume content reflects current scientific knowledge, policies, or practices. 



\section{Insect Pests of Cigar-Type \\ Tobaccos in the Southern}

\section{Districts}

F. S. CHAMBERLIN, Associate Entomologist

A. H. MADDEN, Junior Entomologist

Division of Truck Crop and Garden Insect Investigations

Bureau of Entomology and Plant Quarantine

For sale by the Superintendent of Documents, Washington, D. C. . . . . . Price 15 cents

\section{UNITED STATES DEPARTMENT OF AGRICULTURE}

WASHINGTON, D. C., APRIL 1942

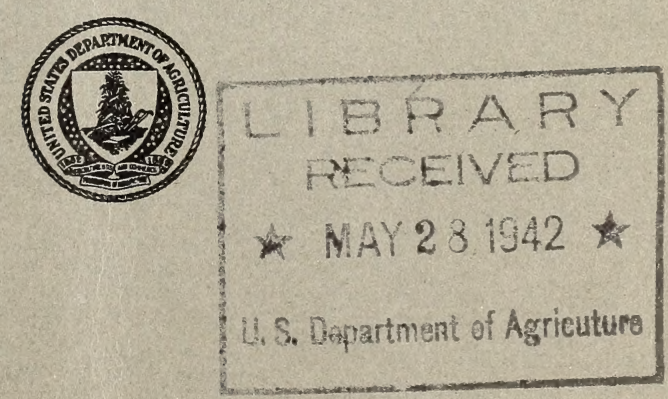





\section{Circular No. 639 \\ April 1942 - Washington, D. C.}

UNITED STATES DEPARTMENT OF AGRICULTURE

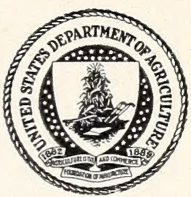

\section{Insect Pests of Cigar-Type Tobaccos in the Southern Districts}

By F. S. Chamberlin, associate entomologist, and A. H. MAdDEn, junior entomologist, Division of Truck Crop and Garden Insect Investigations, Bureau of Entomology and Plant Quarantine ${ }^{1}$

\section{CONTENTS}

Introduction

Insects attacking tobacco in the plant beds Mole crickets

Flea beetles

Cutworms

Insects attacking the crop in the field The tobacco budworm

The hornworms

The tobacco flea beetle

Cutworms...

Grasshoppers

The tobacco thrips

Page
1
3
3
6
6
7
7
16
23
31
36
41

Insects attacking the crop in the field $-\mathrm{C}$ on

The southern green stinkbug

Wireworms

The suckfly

Climbing cutworm

The garden flea hopper

The potato tuber worm, or tobaceo splitworm

Other insects occasionally found feeding on

tobacco

Where insecticides may be obtained

Summary

Page

\section{INTRODUCTION}

The production of cigar tobacco in the southeastern part of the United States is centered around Gadsden and Madison Counties, Fla., and Decatur County, Ga. Three types-wrapper leaf, binder leaf, and filler leaf-are raised in these districts. The wrapper type is grown under artificial shades (fig. 1) while the binder and filler types are produced in open fields (fig. 2).

The hot, humid climate and mild winters of this region are favorable to insect abundance, and these pests are one of the most troublesome factors of tobacco culture. While insects attack all types of tobacco, the wrapper type suffers the greatest reduction in value from such injury. Even a few small punctures in leaves of this type cause a considerable depreciation, because cigar wrappers can be cut only from sound leaf areas. This type can be raised successfully only with the careful use of insect-preventive methods and by the timely application of direct-control remedies. Effective control measures must also be used on the sun-grown types of cigar tobacco or severe damage will result.

This circular is an attempt to bring together in available form all the more pertinent facts concerning the habits and control of the

${ }_{1}^{1}$ The writers are indebted to Lucian L. M. May, field aide, for assistance in the field work during the course of the investigations. 


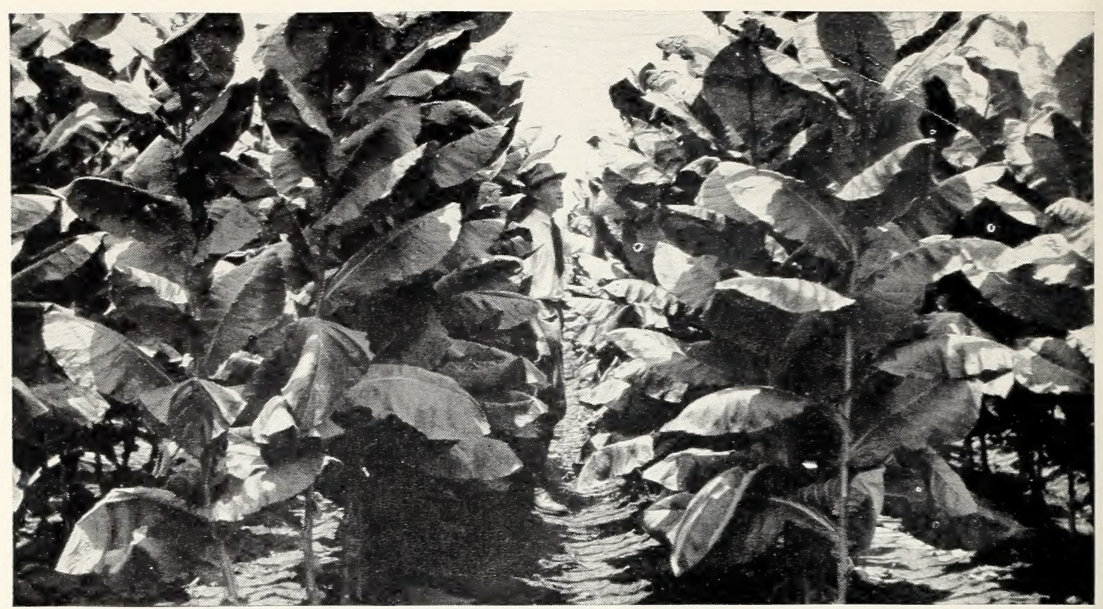

Figure 1.-Cigar-wrapper tobacco growing under artificial shade. The shade structure consists of a wire frame 8 to 9 feet high supported by posts, over the cops and sides of which the loosely woven cloth shading material is spread. In some shades, cloth is the only shading material used, whereas in others wooden laths spaced 3 to 6 inches apart and attached to the wire supporting structure are used with the cloth.

insect pests attacking the crop in this region. It is intended to be an aid to tobacco growers in the solution of the many and varied insect problems which arise in connection with the growing of the crop.

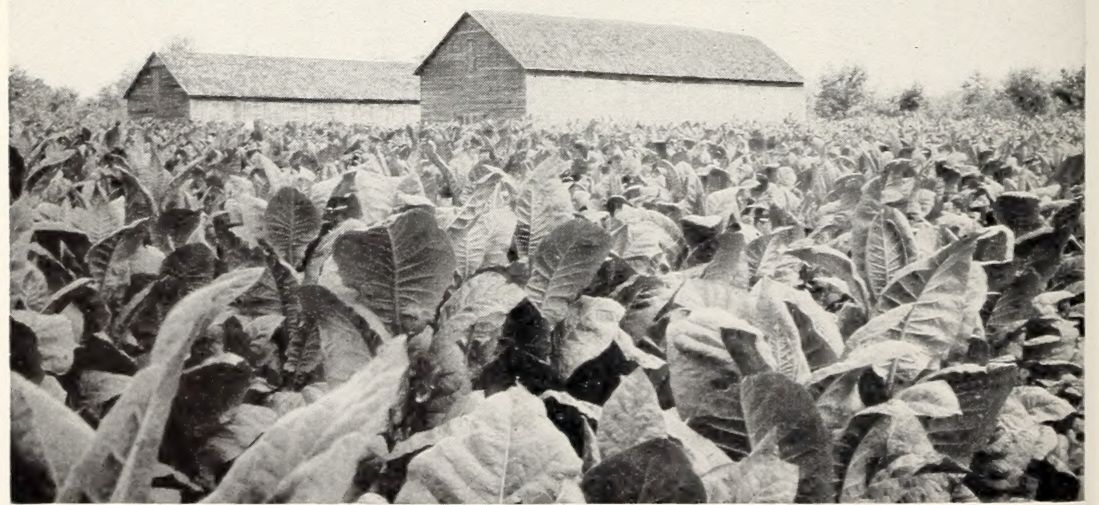

Figure 2.-A field of sun-grown, cigar-filler tobacco of the Sumatra variety; about fully grown. 


\section{INSECTS ATTACKING TOBACCO IN THE PLANT BEDS}

Insects normally cause only slight damage to the tobacco in the plant beds of this region. The beds are planted early in the spring when some pests are still in hibernation, and when other injurious species, while present, have not had sufficient time to produce harmful infestations. The soil is treated with live steam (fig. 3) or burned with wood fires prior to the sowing of the seed to destroy weed seeds, parasitic fungi, and insects present in the topsoil. The cloth tops and sidewalls used on beds (figs. 4 and 5) are important factors in reducing infestations of budworms, cutworms, and other destructive insects. These coverings, which serve as protective barriers, should be kept intact throughout the plant-bed season as far as possible. When disease attacks the tobacco plants in beds, growers sometimes

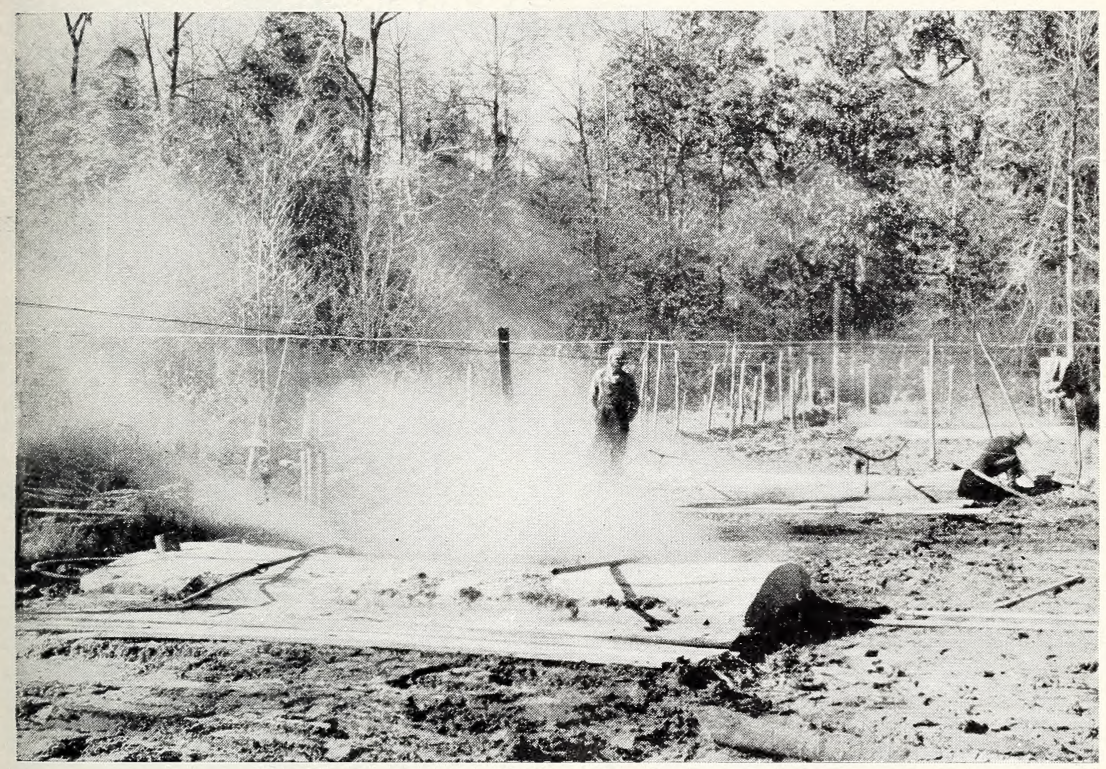

Figure 3.-Steaming the soil in a tobacco plant bed, prior to sowing the seed, for the purpose of killing weed seeds, disease organisms, and insect pests that may be present in the surface soil.

remove the cloth cover to admit additional sunlight and air, believing that this reduces the rate of spread of the disease. Under these conditions the plants frequently become infested with eggs and small larvae of budworms, cutworms, and other insects. These pests may develop sufficiently to cause appreciable damage in the beds and also may be carried into the field on the young plants, where they will produce severe injury if not controlled immediately.

The injurious insects that are found most frequently in the tobacco plant beds of this region are mole crickets, flea beetles, and cutworms. These may occur in sufficient numbers to require control remedies.

\section{Mole Crickets}

The southern mole cricket (Scapteriscus acletus R. and H.) and the changa (S. vicinus Scudd.) (fig. 6) have been increasing in im- 


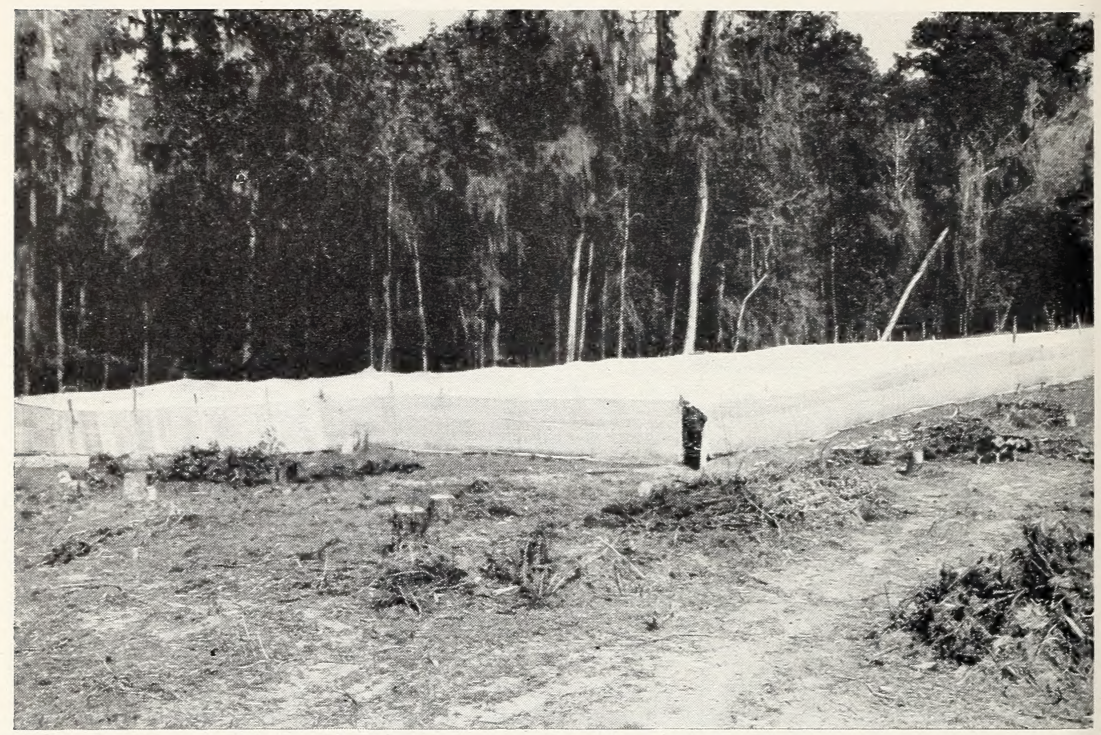

Figure 4.-Tobacco plant bed containing 1,000 square yards, covered with tobacco shade cloth containing about 12 threads per linear inch.

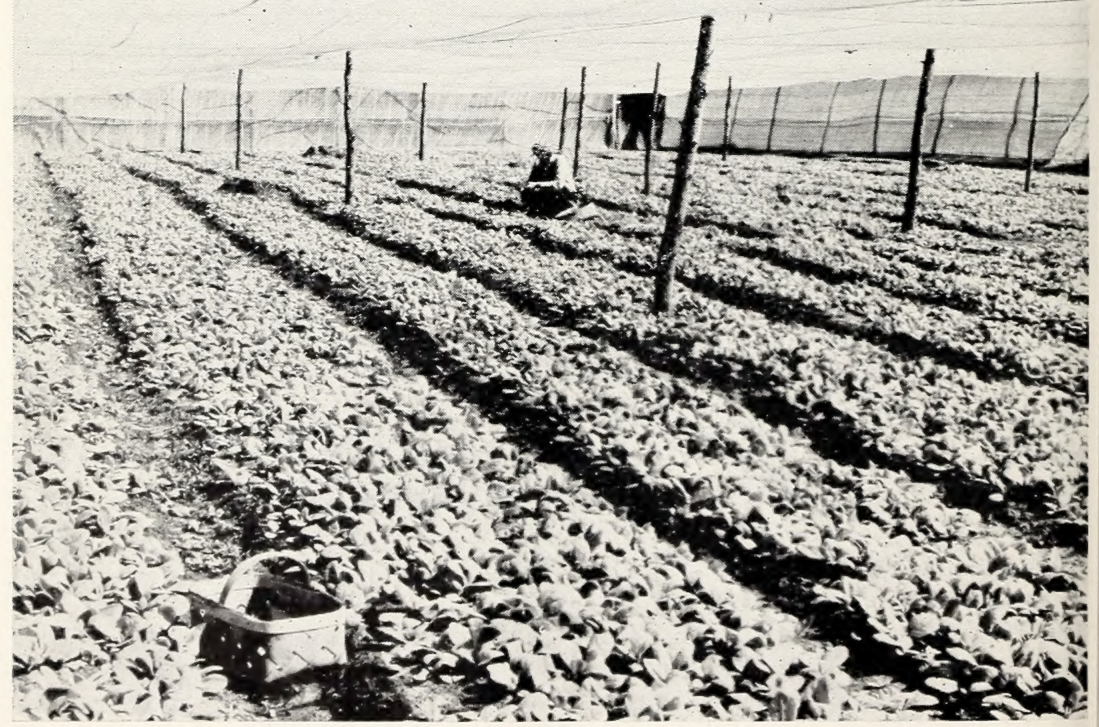

Exgure 5.-Tobaceo plant bed, interior view, showing method of spacing the individual beds of 3 -foot width. 
portance as plant-bed pests in this region during the last few years. In this locality these insects are usually not harmful to tobacco plants after they are set in the field, the damage being confined almost entirely to plants in the beds. The damage is especially evident during periods of warm, wet weather, at which times mole crickets are most active near the surface of the soil. Favorable surface-moisture conditions may exist in the plant beds, however, even during dry weather, since in most cases the beds are kept moist by some form of irrigation.

Observations show that in general these insects do not actually feed on the plants or their root systems, apparently being attracted to the beds mainly by the cottonseed meal used as fertilizer. Injury to the plants results from the burrowing activities of the mole crickets just beneath the surface of the soil. Frequently many plants are uprooted and killed during the course of these burrowing activities, and in addition such burrows break the capillarity existing between the water table and the surface, causing the soil to dry out. This not only injures or kills the plants already above the ground, but it may also prevent germination of the seed in the soil. The damage may be counteracted to a considerable extent by the use of overhead irrigating systems or by watering with a hose or sprinkling can. Water falling from above not only moistens the surface of the ground but also causes disturbed areas and uprooted plants to settle back into place. Since this is not fully effective, however, control measures must sometimes be used against these pests.

Applications of poisoned bait usually provide satisfactory con-

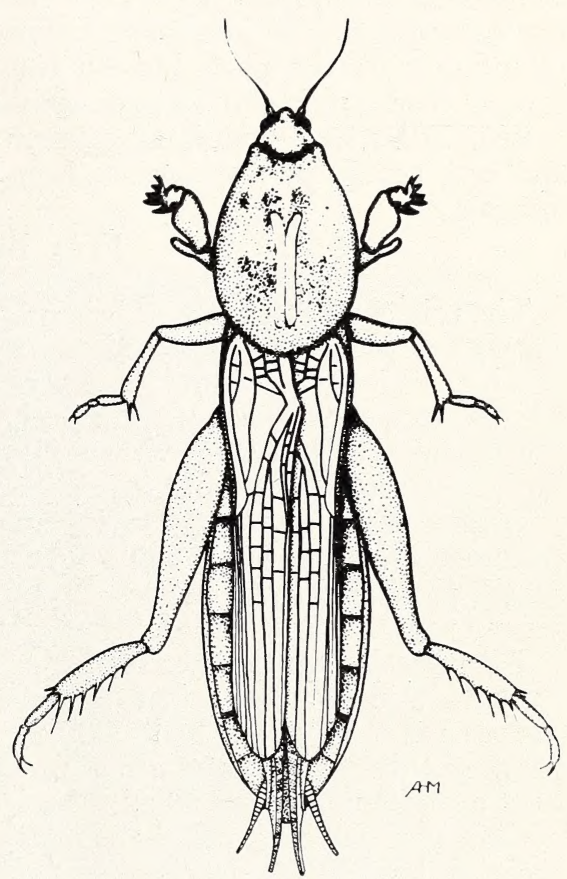

Figure 6.-Adult changa (Scapteriscus vicinus), dorsal view, about $\times 2^{1} \frac{1}{2}$. trol. The formula of a bait which may be used for this purpose is as follows:

Pounds

Cottonseed meal or corn meal

Bran or shorts

5

Calcium arsenate or paris green

Water to moisten.

The dry ingredients should first be mixed thoroughly to insure complete distribution of the poison. The mixture is then carefully moistened with water so that when a handful is pressed together and released it will fall apart with a crumbly consistency. Sirup or molasses may be added to the water in the ratio of 1 part to 10 , but recent experiments have demonstrated that sirup does not increase the effectiveness of the bait. 
After it is mixed, the bait should be applied within 48 hours at the rate of about 1 pound (dry weight) per 100 square yards of plantbed surface. It may be scattered broadcast over the entire bed if the application is being made prior to the germination of the seeds. After germination or the appearance of the plants above ground, the bait should be scattered between the rows, and extreme care should be exercised to avoid throwing any of the particles on the plants themselves or on the areas in which the seeds are planted. If this precaution is not taken, severe burning of the plants may result.

For the best results, applications should be made as late as possible in the afternoon, and at a time when the surface of the soil has been moistened thoroughly by recent rainfall or by irrigation. The number of applications necessary will vary with local conditions and the abundance of the pest, but on the average two applications spaced several days apart should give satisfactory control.

CAUTION : Bait containing calcium arsenate or paris green is poisonous, and care should be exercised to keep it away from poultry and domestic animals.

\section{Flea Beetles}

The tobacco flea beetle (Epitrix parvula (F.)) is frequently found in tobacco plant beds, but seldom causes severe injury to the seedlings in this region. In some instances, however, these insects are sufficiently numerous to necessitate control measures. Occasionally the potato flea beetle (Epitrix cucumeris (Harr.)) is found also attacking young tobacco plants in seedbeds.

Injury in beds usually begins around the margins and may spread over the entire area. If the infestation occurs when the plants are small, those fed upon may be completely destroyed. Feeding on the larger plants stunts and delays their growth.

Flea beetles can be controlled in tobacco plant beds by applying a dust containing 1 percent of rotenone at the rate of 8 ounces per 100 square yards of plant bed. Either a home-mixed or a commercially prepared dust may be used. Directions for preparing a home-mixed dust are given on page 28 of this circular.

Clay and finely ground tobacco dust are used as diluents in commercial brands of derris and cube dust. Both these diluents are satisfactory for use on tobacco plant beds. If tobacco dust is used it should be certified by the manufacturer as being sterilized and free from pathogenic organisms which might produce tobacco diseases. An efficient rotary, hand-operated duster should be used to apply the poison mixture to the plants, and coverage should be as uniform as possible. One or two applications of the dust are usually sufficient to control the limited infestations of flea beetles that attack the plant beds in this region.

\section{Cutworms}

Although cutworms are injurious mainly to newly set tobacco, they frequently cause some damage in the plant beds. Young larvae eat small portions from the tobacco leaves, while the large worms may destroy whole clusters of small plants. In spite of board and log barriers at the edges of beds, cutworms often work their way in from surrounding areas. Infestations are usually confined to the margins, but they may extend over an entire bed. 
In case cutworms are found to be causing damage in plant beds, control may be effected by applying poisoned-bran bait. The formula and preparation of this bait are described in detail on page 34 of this circular. The bait should be scattered around the margins of infested beds, in the walkways, and in any open spaces where the plants are missing. The bait should not be thrown onto the tender plants, as this will cause considerable burning of the foliage. As cutworms feed mainly at night it is desirable that the application be made late in the afternoon, near sundown, so that the bait may be fresh and attractive when the insects become active. About 4 pounds (dry weight) should be used to each 100 square yards of plant bed.

\section{INSECTS ATTACKING THE CROP IN THE FIELD}

\section{The Tobacco Budworm}

The tobacco budworm is one of the major insect pests of cigar tobacco in the southern districts. In this region budworm attacks

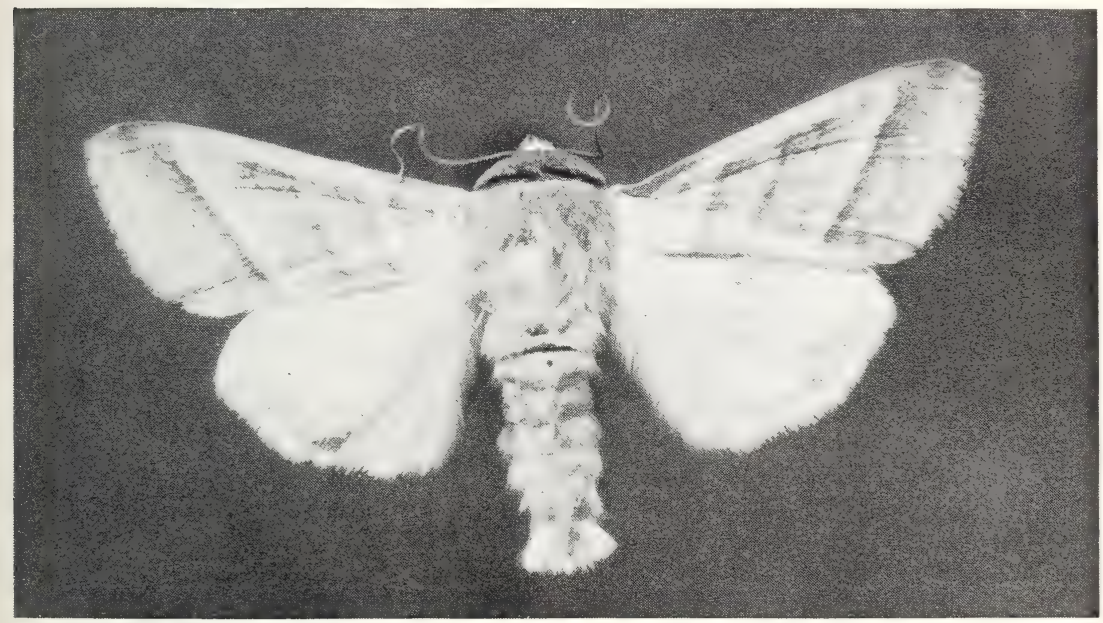

Figure 7.-Adult, or moth, of the tobacco budworm, about $\times 2 \frac{1}{2}$.

are almost exclusively by the tobacco budworm (Heliothis virescens (F.)), whereas in certain other sections of the United States and in Jamaica the bollworm, or corn earworm (Heliothis armigera (Hbn.)), also attacks tobacco in appreciable numbers. Although the budworm feeds on all types of tobacco grown in this region, injury to leaves to be used as cigar wrapper is more serious than injury to leaves of other types owing to the expense connected with the production of wrapper tobacco and the fact that soundness of leaf is of greatest importance in this type. The infestations occurring in the binder and filler types, however, are so great as also to necessitate control practices.

\section{DESCRIPTION AND HABITS}

The small, whitish eggs from which the budworms hatch are deposited by a greenish-colored moth (fig. 7). They are laid singly, 
usually on the under side of the upper tobacco leaves. The small budworms crawl to the bud. or terminal, of the plant, where they conceal themselves between the immature leaves and begin to feed ravenously. From 18 to 31 days are required for

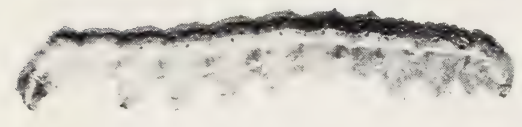

Figroe 8.-Mature larra of the tobalco budworm, about $\times 1 \frac{1}{3}$. their development in May and June. At maturity they attain a length of about $1 \frac{1}{2}$ inches (fig. 8). They are commonly light green, with paler strips running lengthwise of the body, but the color may range from green to yellowish or dark brown. When fullgrown the budworm enters the soil and changes to the pupal, or resting, stage (fig. 9).

\section{CHARACTER OF INJURY}

Injury to the tobacco plant is caused by the larva of the budworm. Although some damage is done by the larger larvae feeding on the mature foliage, the greater part of the injury is produced in the small, immature bud leaves (fig. 10). Distorted leaves often result from feeding on the tips of the leaves in the developing bud. When the attack is made elsewhere, large unsightly holes develop as the leaf tissue expands (fig. 11). Both types of injury greatly lower the value of wrapper tobacco and depreciate the value of the sun-grown types. If the worms are not controlled, they may feed on the plants to such an extent as to cause a considerable loss in weight. Frequently the entire bud may be eaten away with the consequent stunting of the entire plant.

\section{NATURAL ENEMIES}

If it were not for the assistance of numerous parasitic and predaceous enemies of the budworm, the infestations in tobacco fields would undoubtedly be much greater. One of the important predaceous enemies is a greenish spider. Pencetia ividans Hentz (fig. 12), which is extremely common on tobaceo in this region. Inother enemy is a wasp, Polistes sp., which destroys many of the larger larvae.

I fly. Sarcophaga Tambens. Wied. (stemodontis Towns.), closely resembling the conmon housefly (Musca domestica L.) acts as a parasitic enemy of the budworm. It deposits small maggots in the body 
of the worm. These maggots feed within the body of the host and finally destroy it.

From the standpoint of economic importance a black-winged, redbodied, wasplike insect, Cardiochiles nigriceps Vier. (fig. 13), stands first among the several species of parasites that attack the tobacco budworm in the tobacco-producing sections of Georgia and Florida. When the weather is bright and warm this insect is often seen hovering around tobacco plants. Upon finding a small budworm the insect quickly inserts an egg into its body. Many young budworms seem to die almost immediately as the result of this attack, although the majority approach maturity before they succumb. As the parasitized

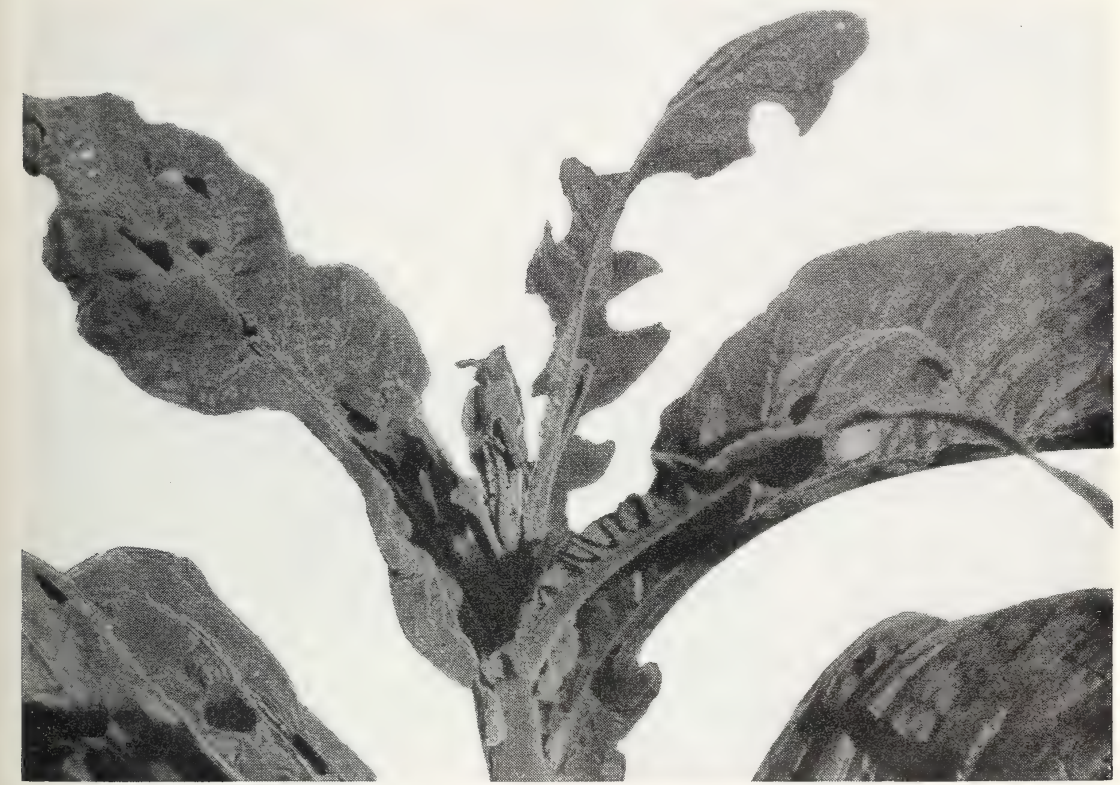

Figure 10.-Tobaceo bud showing serious budworm injury.

tobacco budworm continues to do serious damage throughout its entire period of growth, it is evident that the benefit derived from this parasite is more cumulative than immediate.

During the early part of the tobacco-growing season the parasite is observed only rarely, but as the season advances its numbers rapidly increase. In July and August parasitization by this species sometimes averages from 50 to nearly 100 percent.

\section{CONTROL MEASURES}

THE USE OF POISONED BAIT

The budworm may be controlled very effectively until after the plants are topped by applying to the tobacco buds a mixture of lead arsenate and corn meal in the ratio of 1 to 75 by weight. The corn meal is more attractive to the budworm than is the tobacco leaf, and 
serves not only as a poison carrier but as a bait. The mixture is a quick-acting poison, and only a small quantity per plant is necessary to control the budworm. When properly applied the mixture seldom causes injury to the tobacco foliage.

The results of a large number of experiments have revealed no satisfactory and less expensive substitute for the lead arsenate-corn meal mixture. One of the most promising carriers tested was whole corn meal which consisted of the grain, cob, and shuck ground to the approximate fineness of corn meal. This mixture did not have

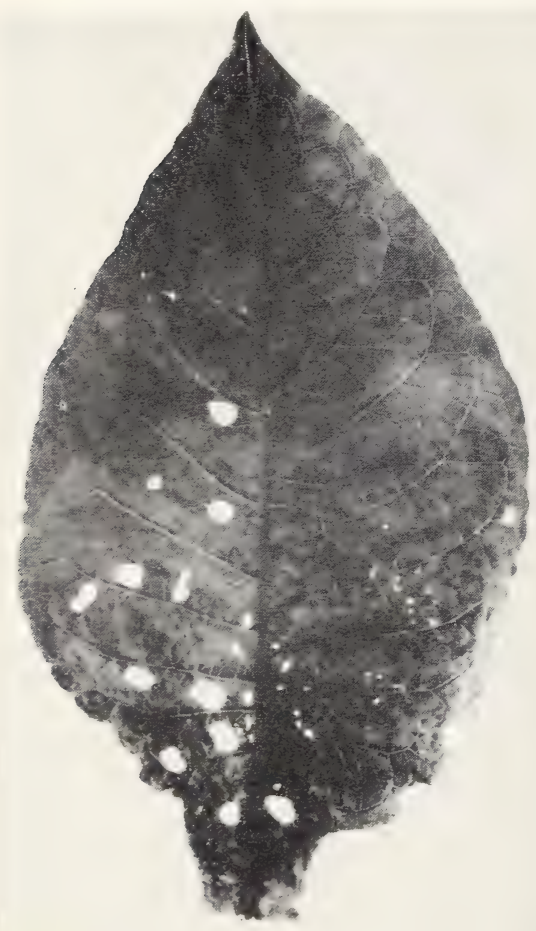

Figure 11.-Leaf of shade-grown tobacco 11 by 16 inches, showing injury caused by the budworm. quantities of the bait can be prepared by mixing the ingredients by hand in a bucket or some other container. Mechanical nixers can be employed to adrantage where large quantities are needed.

\section{THE APPLICATION OF THE BAIT}

A small quantity of the poisoned bait should be dropped into the center of the bud. The necessity of applying the mixture directly to the bud is especially emphasized, since applications carelessly made are of small value. The poison applications should be beguin as soon as the plants have become established in the field. The first two or three applications may be made by means of a quart 
can with 10-penny nail holes in the bottom fastened to a stick (fig. 14). As the plants increase in size the bud leaves become more tightly folded and it is then necessary to apply the remedy with the

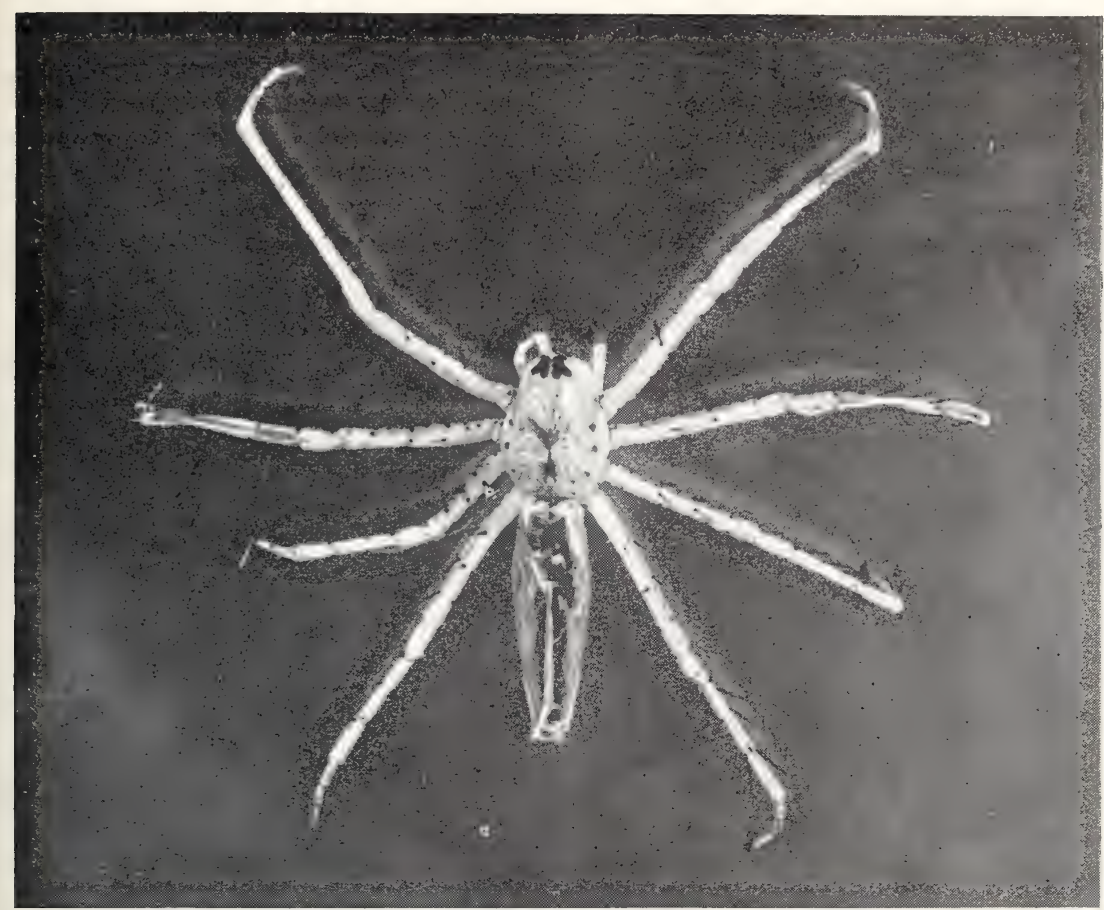

Figcre 12.-A spider, Peucetia viridans, predaceous on the budworm, about $\times 4$.
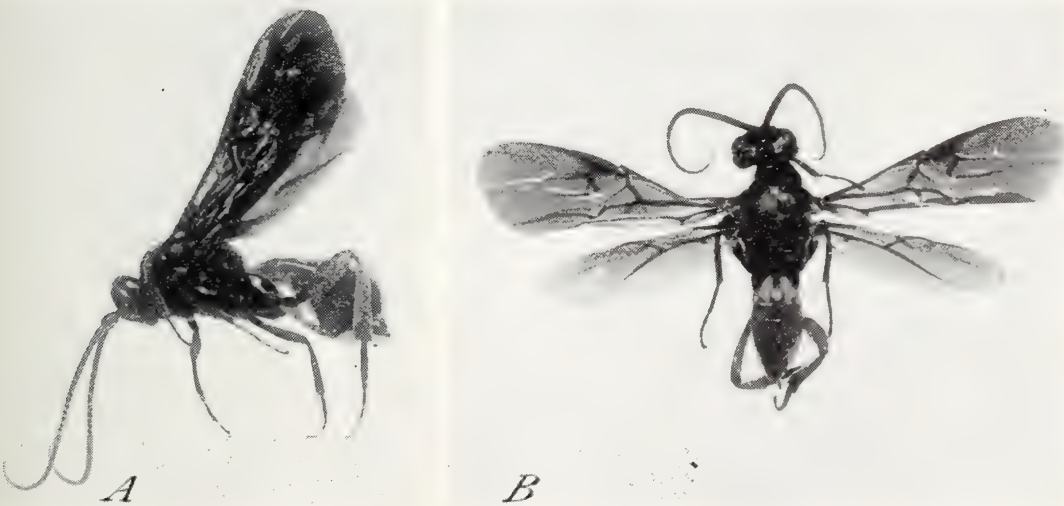

Frgure 13.-Cardiochiles nigriceps, an important parasite of the budworm: $A$, Lateral view; $B$, dorsal view. $\times 4$.

hand (figs. 15, 16, and 17). When the buds are closed they should be opened with one hand while a small pinch of the poison mixture is dropped in with the other. The poisoned bait can be conveniently 


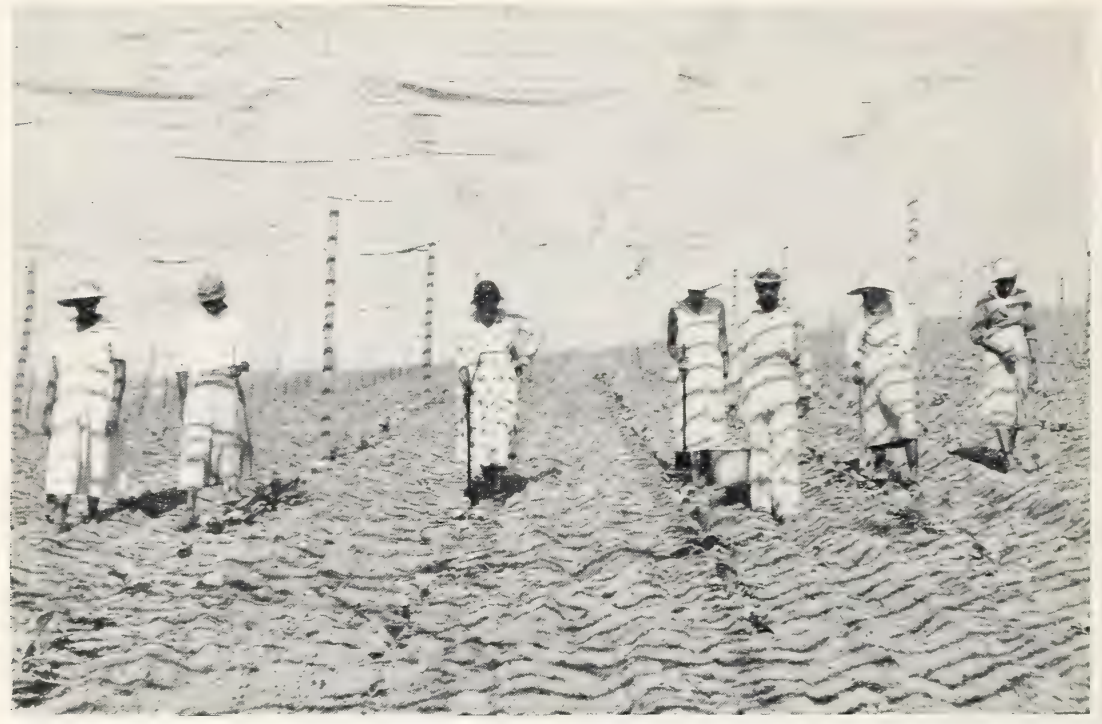

Figtre 14.-Applying the poisoned bait to the buds of newly set tobacco plants by the stick and cup method. The shaded bands on the ground and the workers' clothing are shadows cast by the slats on the shade top.

carried in a small cloth sack or bag, attached to the waist. thus allowing the operator full freedom of both hands. While attempts have been made to apply the bait mixture to the buds with various mechanical contrivances, none of these have proved successful.

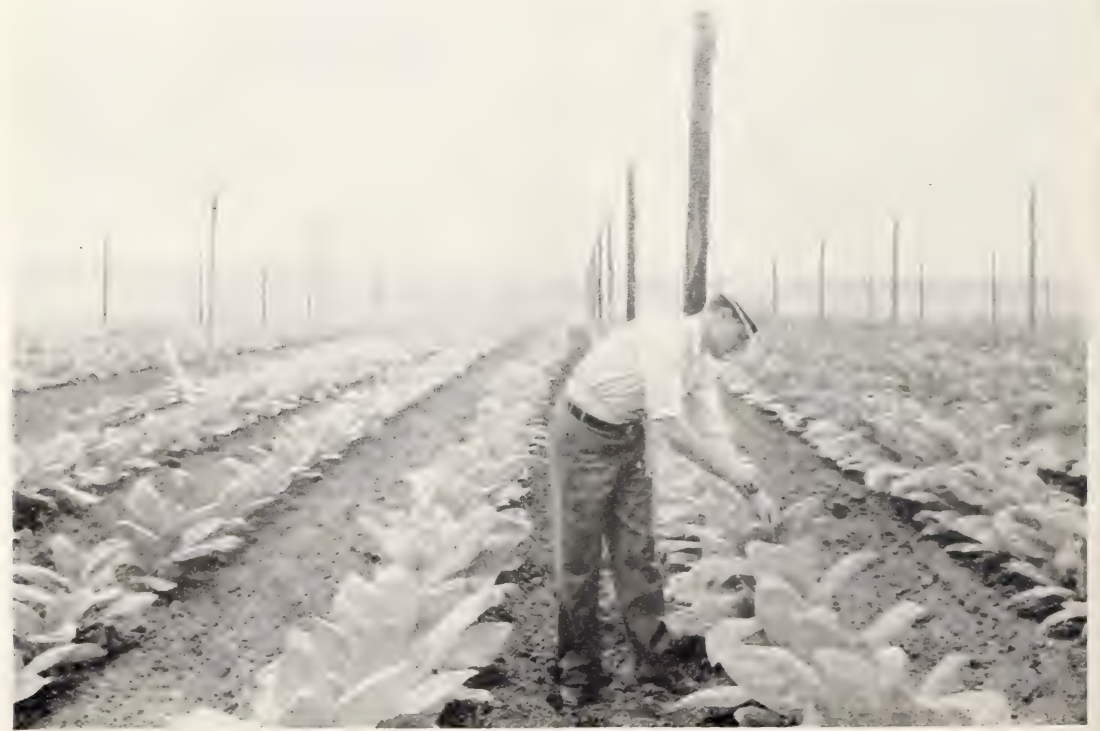

Fir.te: 15.-Applying the poisoned bait to the buds of knee-high shade-grown tobacco. The rate of application is about 10 to 12 pounds per acre. 


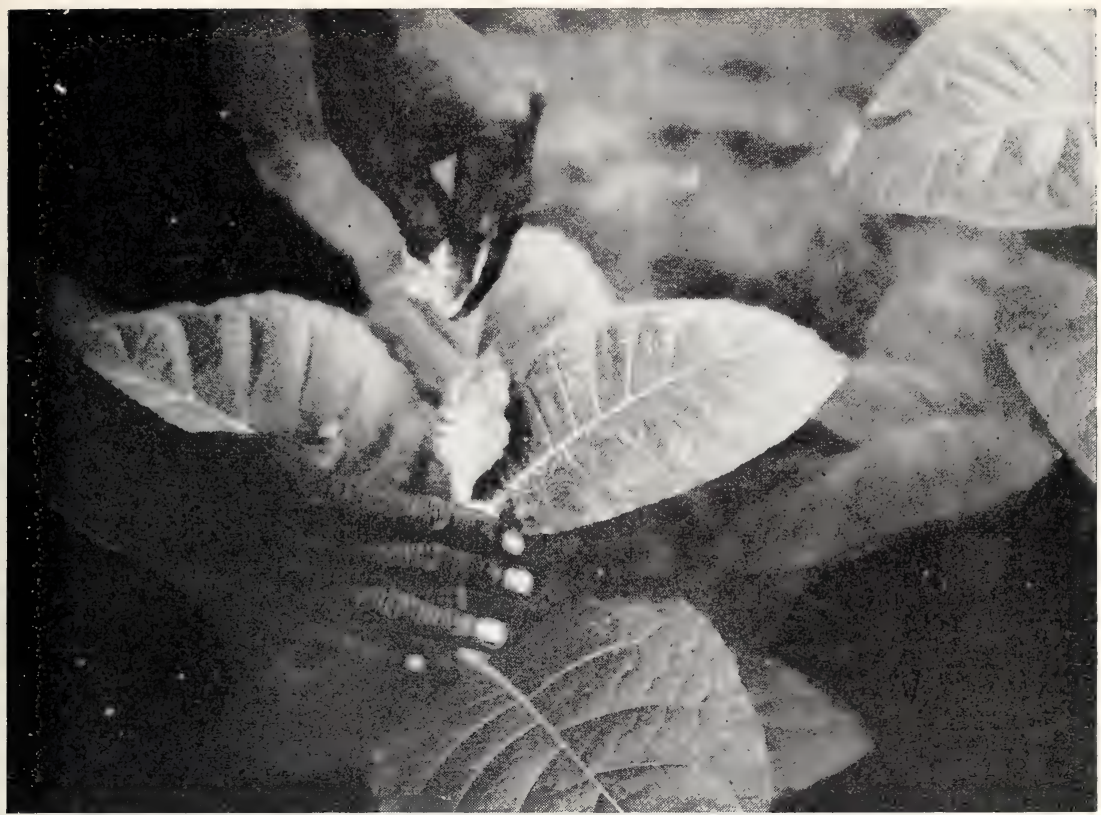

Figure 16.-Applying poisoned bait to the bud of a shade-grown tobacco plant with the fingers.

About 10 to 12 pounds of the mixture per acre should be used for each application. In shade-grown tobacco, where extreme care is taken with applications, somewhat smaller amounts per acre give

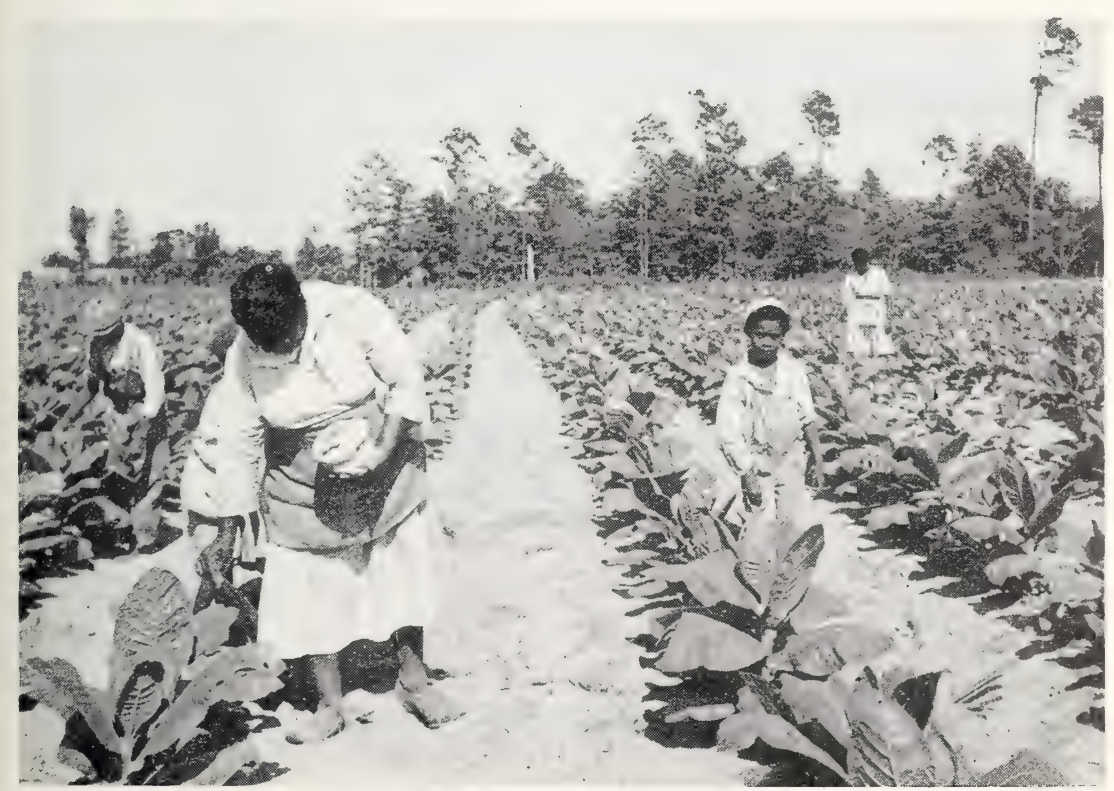

Figure 17.-Applying poisoned bait for the butworm to sun-grown, cigalr-filler tobacco. A worker can treat about $1 \frac{1}{2}$ acres in a day. 
satisfactory control. In periods of excessively wet weather the mixture should be applied very sparingly to the buds, as heavy deposits of the material under these conditions will cause injury to the tender leaf tissues. The mixture should not be applied to the buds when they are wet from recent rains. In the case of shade-grown tobacco at least two applications a week are necessary to protect the buds during normal growing weather. When growth is much retarded by drought and the poison mixture is not removed by rain, one application per week may be sufficient. Care should be taken to prerent any excessive accumulation of the poisoned meal on the ground around the base of the stalk, as this sometimes favors a fungus growth harmful to the plant. This may be avoided by using the proper amount of bait. The poisoned corn meal should not be spilled on the maturing leares, as this may cause burning, especially during periods of wet weather.

In the case of sun-grown tobacco the number and frequency of poison applications necessary to protect the crop will rary from one season to another. Filler tobacco will ordinarily be protected sufficiently by one application each week, while crops raised for cigar binder require about two applications of the poison mixture each week.

CONTROL AFTER TOBACCO IS TOPPED

After the plants are topped the poisoned bait can no longer be used. Control during the remainder of the season is a more difficult matter, and especially so on shade-grown tobacco. Fortunately the insect usually confines itself to the suckers and to the less valuable upper leaves of the plants during this period. Budworms attacking the upper portions of maturing tobacco are locally called "seedrorms." as they feed on the seed pods as rell as on the foliage. Infestations may be reduced to a considerable degree by applying the poisoned bait to the buds just prior to topping the plants.

Light dust applications of paris green are frequently used to control the budworm and the hornworm on cigar tobacco during the latter part of the growing season. Unfortunately these applications exert only a partial control, since the budworms are resistant to arsenicals after they have become about half grown. As the use of paris green entails considerable hazard to shade-grown tobacco, its application to this crop is usually advisable only after the more valuable middle leaves have been harvested.

Warning: Paris green is rery poisonous and should be handled with extreme care. The hands should be washed carefully after the poison has been mixed and applied. Operators applying paris green with hand dusters should wear aprons to protect the body from the poisonous dust. Aprons made of oilcloth have been found excellent for this purpose.

The poisons and the mixed bait should be stored in tightly closed containers and not spilled upon the ground where they will be accessible to livestock. All areas on which paris green may be deposited as the result of dusting oprations should be well fenced so that stray animals will not have opportunity to feed upon poisoned grass or weeds.

The poisoned budworm bait consisting of lead arsenate and corn meal is very attractive and poisonous to livestock, and it and paris green should not be accessible to them at any time. 
GENERAL CONTROL RECOMMENDATIONS

Plant beds should be tightly covered with cloth to prevent the entrance of moths. In this way the number of eggs and larvae introduced into the fields will be held to a minimum.

The plants left in the beds should be thoroughly destroyed as soon as the beds are abandoned. If allowed to grow throughout the season, they serve as excellent breeding places for the budworm and other insect pests.

Where tobacco is grown under cheesecloth, preventive measures against the budworms may be practiced with great success. The walls and top of the canopy should be kept intact as far as possible. Cloth-covered gates (fig. 18), which are provided to admit workmen and implements, should be kept closed as much as possible.

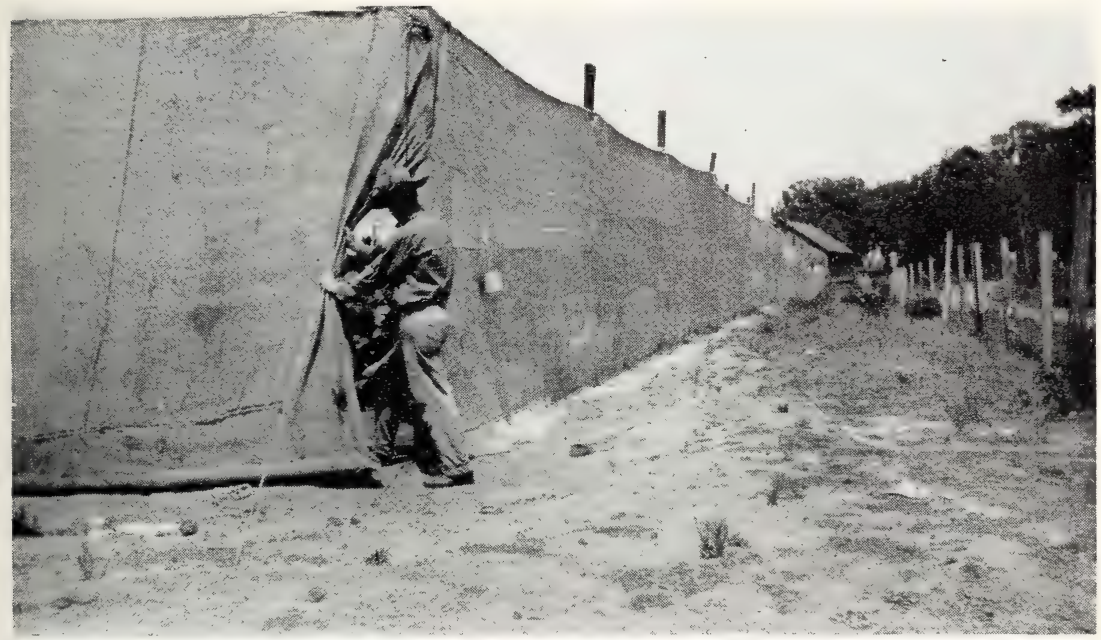

Figure 18.-Cloth-covered gateway to a tobacco shade field. Close-fitting gates of this or similar types prevent the entrance of a considerable number of insect pests.

When the tobacco stalks are topped, the portions of the plants removed are frequently infested with eggs and larvae of the budworm. These infested tops should not be thrown on the ground in the tobacco row, as many of the larvae may crawl up the stalks and reinfest the foliage. They should be placed in sacks, taken outside the field, and destroyed.

The plowing of tobacco fields in the fall or early winter months undoubtedly results in the destruction of many budworm pupae in the soil, thereby reducing the number of moths waiting to emerge the following spring.

Destruction of the tobacco stalks immediately after harvesting the crop (fig. 19) will reduce the number of overwintering budworms by removing the food supply of late-maturing individuals. This practice is also very beneficial in connection with control measures against the hornworm and the flea beetle. 


\section{The Hornworms}

Because of their large size and roracious appetites, the hornworms attacking tobacco are capable of inflicting enormous damage to tobacco leares. Two species occur in the southern regions where cigar tobacco is produced, the tobacco worm (Protoparce quinquemaculata (Haw.)) and the tobacco hornworm (Protoparce sexta (Johan.)). The former occurs in limited numbers and is of little economic importance, but the latter is one of the most destructive insect pests of tobacco in this area. Owing to this fact only the tobacco hornworm is discussed in detail, although the control measures presented are equally applicable to the tobacco worm.

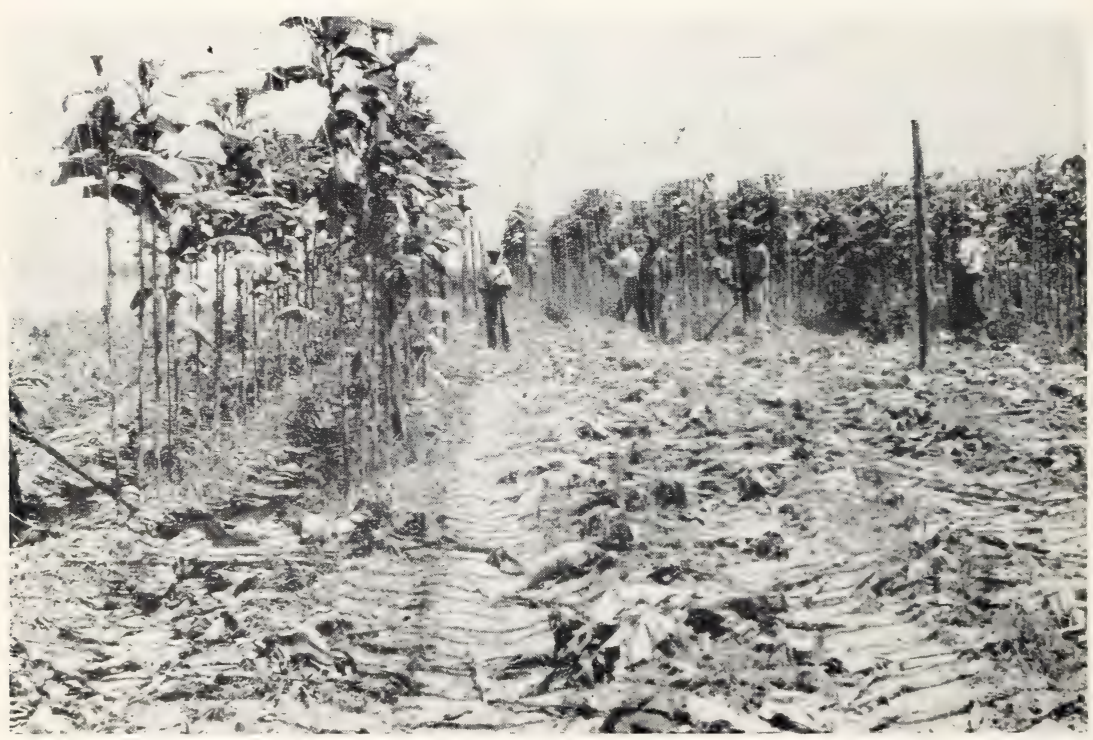

Figlre 19.-Destroping tobacco stalks immediately after harrest. This practice aids materially in reducing the number of late-maturing individuals of the budworm, the hornworm. and the flea beetle.

\section{LIFE HISTORY AND HABITS}

The tobacco hornworm passes through four distinct stages of derelopment during the course of its life cycle. namely, the egg, the caterpillar. or larra, the pupa, and the adult, or moth. The eggs are roughly oval to spherical in shape and are generally greenish white. They are deposited singly by the moths, usually along the outer edges of the lower surface of the tobacco leares, although some may be attached to the upper surface. The incubation period requires approximate $]_{y}$ from 2 to 7 days, depending upon the temperature.

Newly hatched larvae are about three-sixteenths of an inch in length and are rellowish white. Ifter a short feeding period, however, the color changes to pale green, and as development progresses the green color deepens and the characteristic oblique black and white stripes appear on the sides of the body. The arerage duration of the 
larval period is about 3 weeks, and full-grown larvae attain an average length of approximately 31/2 inches. They are usually green with seven oblique black and white stripes on the sides, and the posterior end of the body bear's a short red horn, from which the name "hornworm" is derived (fig. 20, B). It is only in this stage that the hornworm is harmful to tobacco. The larva feeds on the leaves continuously, with the exception of about four periods during the development of the larva, of about 24 hours duration each, when the skin is being shed. The rate of growth and the amount of food consumed increase rapidly during the latter part of the larval period. Thus it is desirable to destroy the worms in the early part of their development. When fully grown the larva enters the soil and changes to the pupa.

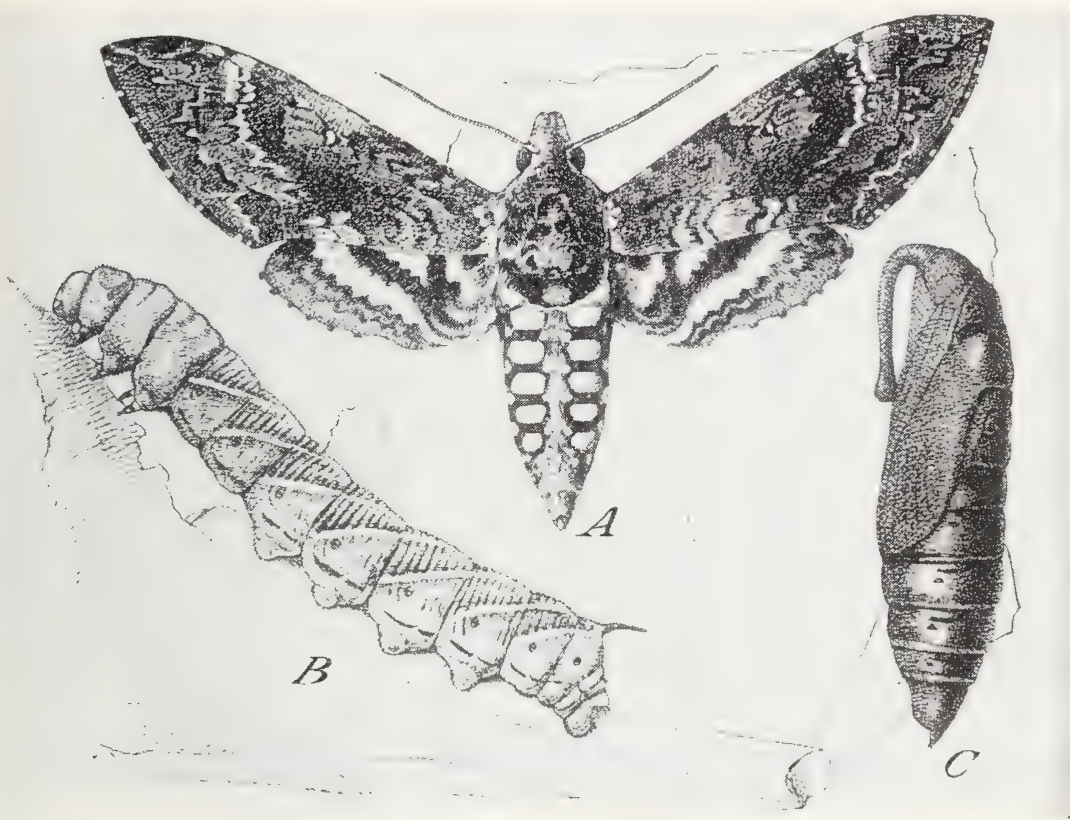

Figure 20.-Life stages of the tobacco hornworm: $A$, Adult; $B$, larva, or caterpillar ; $C$, pupa. All about three-fourths natural size.

The pupa, or resting stage, is spent at a depth of about $51 / 2$ inches below the surface of the ground. This stage may require only about 2 or 3 weeks during the summer. Considerable variation occurs, howerer, and even at this time of the rear many larvae may enter the ground to remain in the pupal condition until the following season before changing into the adult form. Observations also indicate that the pupal stage may require almost 2 years in some instances. The pupa (fig. 20, $($ ) is brown and about 2 inches long.

The adult of the tobacco hornworm is a large brownish-gray moth (fig. $20, A$ ) with a wing spread of about $41 \%$ inches. The forewings have a mottled appearance and each bears a small white spot near its center. The hind wings are darker and are marked by a number of 
broken, oblique, white cross bands. There are usually six pairs of orange-yellow spots on the sides of the abdomen. The moth is active only at night and remains concealed in some protected spot during the daytime.

The hornworm passes the winter in the pupal stage, and, in this area, the first adults of the season begin to emerge between the middle of April and the first of May. Egg laying begins shortly after emergence, and first-brood larvae usually complete their development about the latter part of May or the first of June. Second-brood larvae are generally present in the field early in July and maintain the infestation on tobacco until the harvesting of the crop. Later broods occur after this time, but the number of individuals comprising such broods is relatively small. These individuals feed on late tobacco, and to a limited extent on tomatoes, peppers. and similar host plants. Three complete generations and a partial fourth occur annually in this locality.

\section{FOOD PLANTS}

As far as is known, the tobacco hornworm feeds only on plants belonging to the family Solanaceae. In this area the most important food plant of the larvae is tobacco, and only a very limited amount of feeding occurs on other cultivated plants of this family such as tomatoes, peppers, eggplants, and potatoes. Observations have indicated also that, with the exception of jimsonweed, little or no feeding occurs on the wild solanaceous plants of this region. The adults obtain food from the blossoms of jimsonreed, tobacco, petunia, and other plants.

\section{NATURAL ENEMIES}

A number of birds of this area feed on hornworms, and the pupae are frequently destroyed by moles and skunks. The green spider Pencetia viridans, which attacks the budworm, also attacks the eggs and larvae of the tobacco hornworm. and these stages are sometimes preyed upon by a small green plant bug. Cyptopeltis rarians (Dist.). One of the most important predaceous enemies of this hornworm is a large wasp, Polistes fuscatus var. metricus Say, which feeds on the larvae.

A fly, Sturmia protoparcis (Towns.), closely resembling the housefly (Mirsa domestica L.), is the chief parasitic enemy of the hornworm in this locality. The maggots of this fly feed within the body of the host larra, ultimately causing its death. In many parts of the country a tiny. wasplike insect. A panteles congregatus (Say), is an important parasite of the tobacco hornworm, but in this region its attacks are extremely rare.

Occasionally dead hornworms may be seen hanging head downward from the under surface of tobacco leaves. The bodies of such larvae have become blackened, and they are nearly twice their normal length owing to the stretching of the skin. They have been killed by a bacterial disease which is prevalent in the field during periods of hot, humid weather. This disease, howerer, is of only minor importance as an enemy of the tobacco hornworm in this area.

The natural enemies of the tobacco hornworm are undoibtedly of considerable importance in keeping its numbers down, and if it were 
not for such enemies the infestations in the tobacco fields of this area would probably be much greater.

\section{CONTROL}

\section{CONTROL ON SHADE-GROWN TOBACCO}

The most effective means of controlling hornworms on shadegrown tobacco at the present time is care in keeping the cloth tops, side walls, and gateways intact throughout the growing season. If a shade structure is situated on land which grew crops other than tobacco or tomatoes the preceding season, the chances are very gieat that the soil will contain no hornworm pupae. Under these conditions there should be no/infestation from within. If the walls and

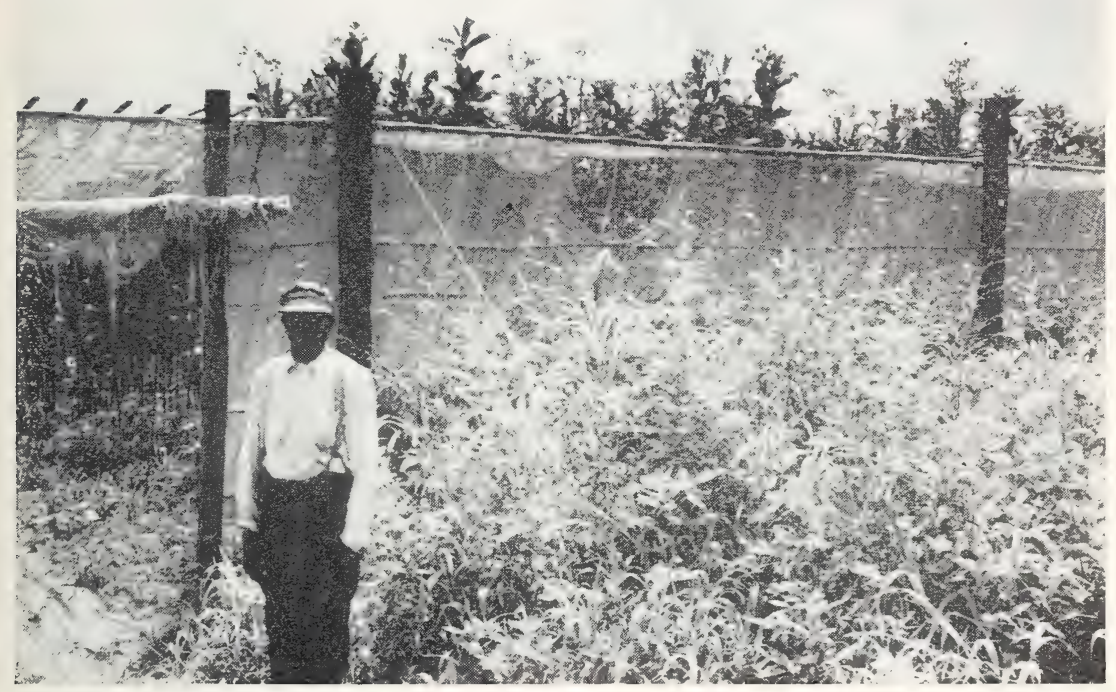

Frgure 21.-Tobacco plants growing through a shate cover. Under such conditions hornworm moths may deposit eggs on the protruding leaves, and the young caterpillars from these eggs work their way downward into the crop.

top can be kept intact, the tobacco will be free from hornworms until the latter part of the harvesting season when the plants reach the shade top. When the plants push against the top, moths on the outside frequently deposit eggs through the cloth onto the leaves which press against it. If the cloth breaks from the continued growth of the plants, the stalks push their way outside and are then available to the moths for oviposition (fig. 21). The caterpillars which hatch from these eggs work their way down into the crop. Usually the main portion of the crop has been harvested at this time, and the larval feeding is largely confined to the top leaves and the suckers.

If a tobacco shade structure is situated on land which contains hornworm pupae from a previous crop, some infestation will occur 
from within. Even under these conditions the walls and top are of much benefit from the standpoint of hornworm control. Many of the moths which emerge within shades go to the walls, where they remain inactive during the daytime. The majority seek shelter in the shade corners, where they may be found clinging to the cloth or to a post. A beneficial practice is to inspect the inside of shade walls each morning and kill all moths found.

The tops and side walls of shade structures are a great protection not only against hornworms but also against budworms, grasshoppers, and sereral other tobacco insect pests. Any breaks in the cloth should be patched promptly, and all possible efforts should be made to lreep the fabric intact throughout the growing season. The side walls should be fastened closely to the ground and should be so constructed that the cloth will not tear where it comes in contact with the posts. The practice of raising the walls to permit the entrance of wagons and farm implements is not to be recommended. The cloth-covered gates that provide entrance to shade fields should be kept closed as much as possible, and especially during the night and early part of evening when the moths are active.

Efforts are being made to find a hornworm insecticide that is safe and efficient, and which leares no disfiguring residue on the cured tobacco. No such material is ret arailable. The poison which comes nearest to fulfilling these requirements is paris green. the main disadrantage of which is its severe burning qualities. If this arsenical is not used with extreme caution. its application may cause more harm than benefit to a crop of shade-grown tobacco. Owing to the hazard involved. it is considered adrisable to omit applications of paris green on tall tobacco until after the valuable middle leares have been harrested. The few hornworms that usually occur on shadegrown tobacco previous to this time should be picked off br hand.

Paris green is applied by means of rotary hand dusters. The dust gun nozzle is held in the center of the space between the tobacco rows so that the dust drifts through the foliage and settles on the leares. When applications are made to tall tobacco the nozzle of the dust gun is directed upward at an angle of about $45^{\circ}$ and to the rear of the operator (fig. 22). Applications of undiluted paris green are made at the rate of about 1 pound per acre. Higher dosages of the poison are made only at considerable risk to the (rop). It is a difficult matter, howerer, to maintain an even distribution of paris green with a maximum dosage rate of 1 pound per acre.

The burning hatard of paris green may be somewhat decreased by mixing 1 pound of the poison with 6 pounds of hydrated lime. The mixture should be applied at the rate of about $t$ pounds per acre. In this manner a smaller quantity of paris green is applied than when the poison is used undiluted. Paris green or mixtures of this arsenical and lime should be applied to the tobaceo foliage only when it is drv.

CONTROY ON SUN.GROWN TOBACCO

The 1-to-f mixture of paris green and lime previously mentioned may also be used to combat hornworm attacks on sun-grown tobacco. but its ue is not entirely satisfactory. The poison and lime should be thoroughly mixed and applied with an efficient rotary duster. On sm-grown tobaceo the applications may be made while the foliage 
is slightly damp with dew but not when wet from rains. Applicaltions made early in the morning or near smolown when there is little breeze are most effective.

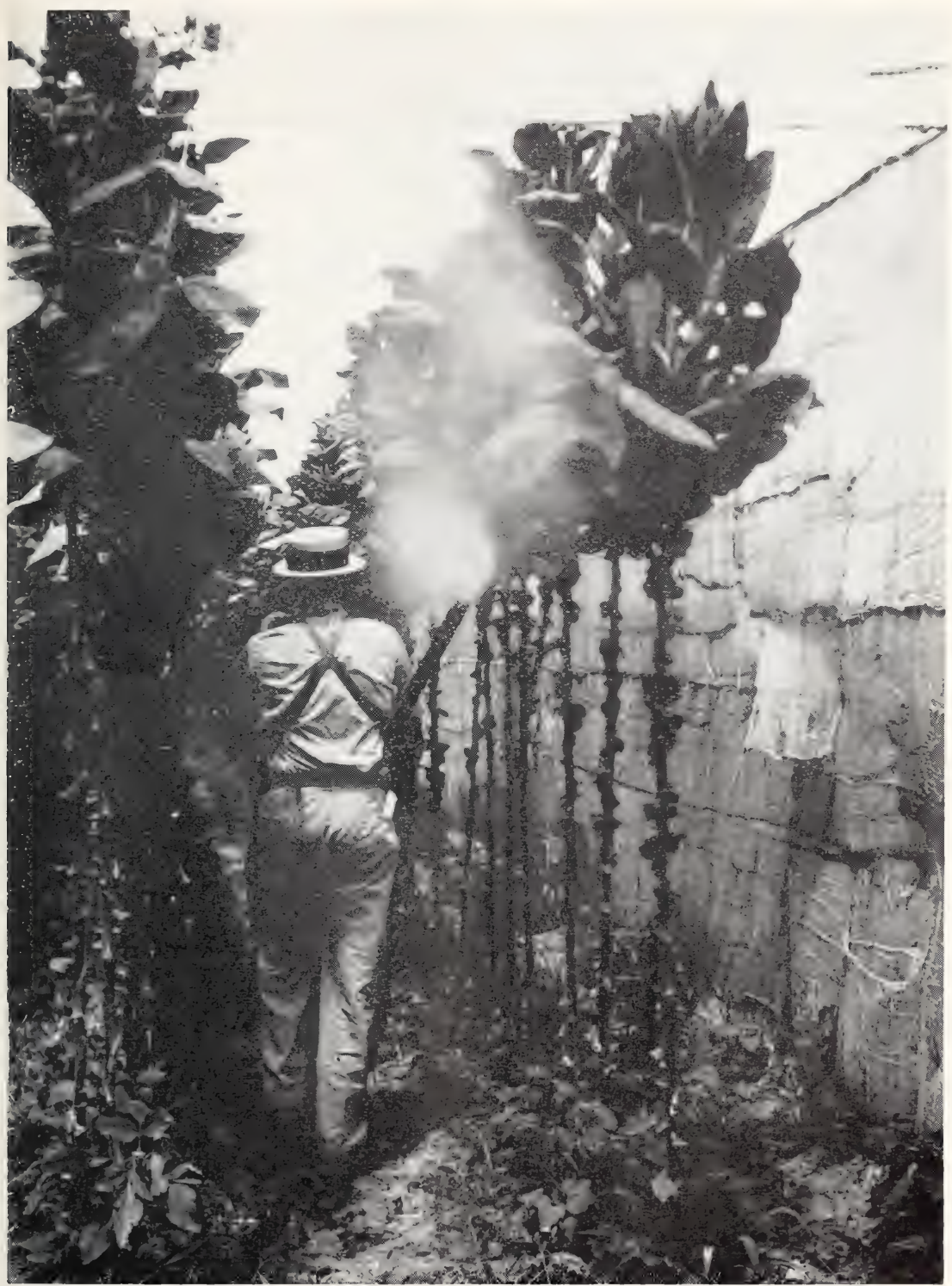

Figtre 2.2.-Applying poison dust to tall, shade-grown tobaceo. The dust-gum nozzle should be directed to the rear of the operator and upward at an angle of about $45^{\circ}$ as shown.

When the tobacco plants are not over knee high. the lust may be directed against the foliage for best results (fig. 203). When applications are made to older tobaces the dust-gun nozzle should be held in the center of the space between the tobaceo rows so that the dust 
cloud formed will settle on the foliage. This is essential to aroid serious burning of the maturing leaves. In high tobacco the dustgun nozzle should be directed to the rear of the operator so that as much as possible he will avoid inhaling the dust. Applications of the poison mixture should be made at the rate of from 7 to 8 pounds per acre. Poisoning operations should commence as soon as the worms begin to hatch in appreciable numbers, and the frequency of the applications during the remainder of the season will depend on the abundance of the hornworm and the purpose for which the tobacco is grown. Filler tobacco will ordinarily be sufficiently protected by about one application each week, whereas crops raised for cigar binder may require two applications of the poison mixture each week.

The paris-green-lime mixture can be recommended for use only with an efficient dust gun and in the manner described. It cannot

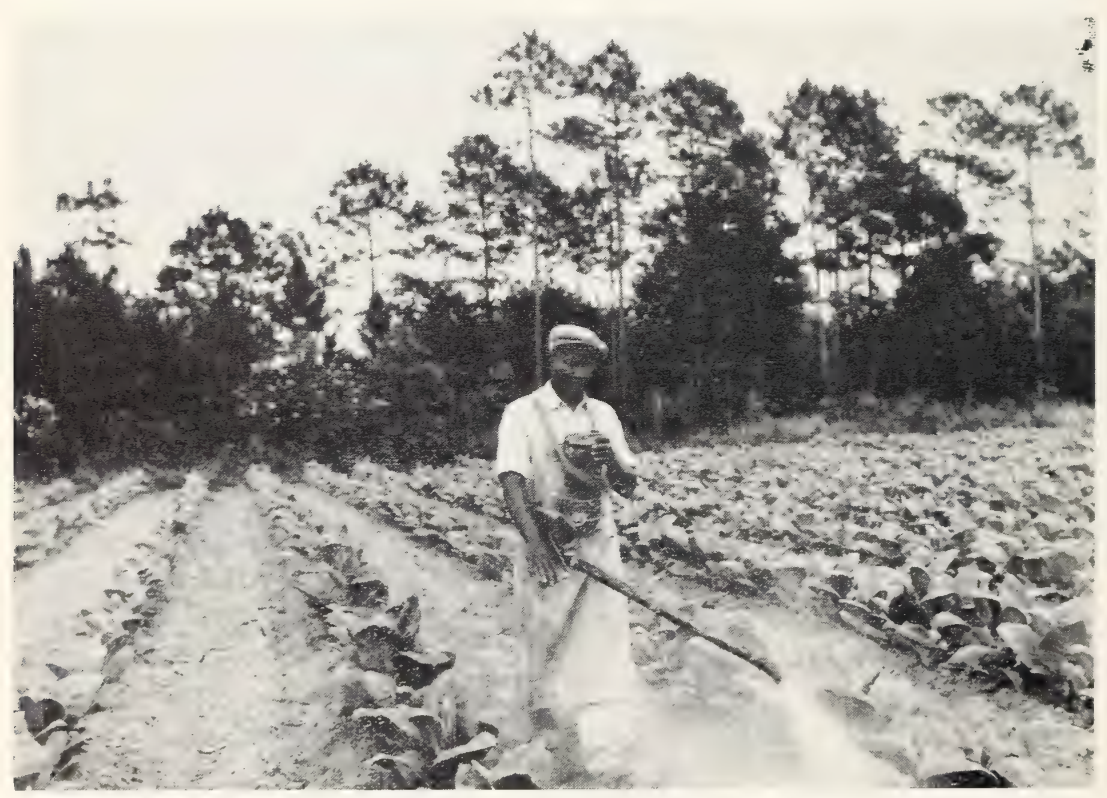

Figure 23.-The proper method of applying poison dust to soung, sun-grown tobacco. When the plants are not over knee high, the dust should be directed against the foliage in order to obtain the best results.

be recommended for use as a spray or for application in dust form by means of the sack "shaker" method, or by any other method that results in heary dosages of the poison being deposited directly upon the plants.

Light applications of undiluted paris green may be used to control the hornworm on sun-grown tobacco in this region. The poison is usually applied at the rate of from 1 to 2 pounds per acre with the dust-gun nozzle held in the center of the space between the tobacco rows. Growers accustomed to the use of the undiluted arsenical frequently obtain a satisfactory degree of control with little foliage injury. while in other instances severe burning results from this practice. 
While calcium arsenate is sometimes used as a hornworm poison, its use in this tobacco-producing area has generally been found unsatisfactory. In numerous tests this arsenical proved to be rather ineffective as a hornworm insecticide, and under some conditions it caused severe burning of the tobacco foliage.

CULTURAL CONTROL METHODS

As no entirely satisfactory hornworm poison is available at the present time, full use should be made of the cultural control measures.

All tobacco stalks should be destroyed as soon after the harvesting season as possible. If the stalks are infested with maturing worms at this time, any foliage left on them should be dusted heavily with paris green. Studies on the hornworm have shown that the greatest abundance of this pest occurs during the latter part of the tobaccogrowing season and that tobacco is practically the only host plant of importance in this area. It is therefore quite apparent that the destruction of larvae and their food supply at this time will appreciably reduce the infestation during the following year.

Hornworms overwinter in the soil at an average depth of $51 / 2$ inches while a small percentage penetrate to a somewhat greater depth. Hibernation is a very critical period in the seasonal history of this insect and only about one-fourth are able to survive under natural conditions. If the pupal cells are disturbed by plowing or other artificial means an additional mortality occurs.

Experimental work has shown that one fall plowing of the soil to a depth of about 7 inches killed about one-half of the pupae which would otherwise have passed the winter successfully. A still greater mortality would be expected to result from several cultivations of soil infested with pupae.

The benefits derived from the early destruction of tobacco stalks and from fall plowing are naturally greatest when practiced by an entire community.

\section{The Tobacco Flea Beetle}

The flea beetle is an important tobacco pest in this region. On the sun-grown filler and binder crops the damage produced by this insect is usually of little economic importance, but on shade-grown cigar-wrapper tobacco it is capable of causing heavy losses. Fortunately, newly developed insecticides have proved very effective in the control of the flea beetle in this region. With a knowledge of the insect's habits and the careful application of the available control remedies, this insect should not be considered a menace to the crop.

While the potato flea beetle (Epitrix cucumeris (Harr.)) is also found in the plant beds and tobacen fields of this region, the infestations consist mainly of the tobacco flea beetle (Epitrix parvula (F.)).

\section{LIFE HISTORY AND DESCRIPTION OF STAGES}

In its life cycle the tobacco flea beetle passes through four distinct stages, the egg, the larva, the pupa, or resting stage, and the adult beetle. It is only in this last stage that the flea beetle is known to the tobacco grower, the other three stages being rarely, if ever, seen. 
The egg (fig. 24), which is about one-sixtieth of an inch long, is oral and pearly white. It is deposited by the female beetle on or near the surface of the soil in cracks and crevices. If the tobacco has been newly set the eggs are usually laid in the moist depressions at the base of the stalk where the plant is watered at setting time. Later in the season, when the plants are larger, most of the eggs seem to be deposited some little distance aray from the stalk, beneath the lower leares resting on the ground. A study of overwintered females

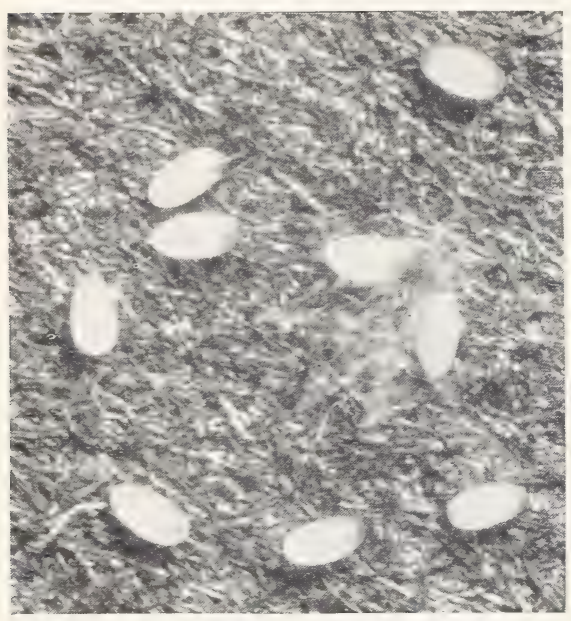

Figtre 24.-Eggs of the tobacco flea beetle, about $\times 20$. under caged conditions indicates that they may deposit at least 200 eggs each. In the early spring months the eggs hatch in about 11 days, whereas in the summer they usually hatch in about 5 days. The moisture content of the soil influences the hatching of the flea beetles' eggs to a marked extent. Eggs placed by the beetle upon air-dry soil fail to hatch, and a comparatively low hatch occurs if the eggs are placed on soil that is only slightly moistened.

The egg hatches into a small whitish caterpillar, or larva (fig. 25), about one-thirtieth of an inch long. Then first hatched these larrae begin an active search for food. The natural food of the larva is the small fibrous rootlets of the tobacco plant and other plants of the family Solanaceae. The young larrae frequently tumnel into the roots, whereas the older larrae usually gnaw completely through them. As the small roots may be completely serered from the plants. the larrae probably do considerable damage when they occur in large numbers. During the cool weather of early spring the larval period lasts about 29 days but in the hot weather of midsummer this time is shortened by nearly one-half. When full-grown the larra attains a length of approximately three-sixteenths of an inch (fig. 26).

The pupa, or resting stage, is passed in a small oval-shaped cell just below the surface of the soil. In this stage (fig. 27 ) the insect more nearly resembles the adult form, the legs, antennae, and wings being plainly seen folded under or about the body. In the spring this stage requires about $71 \%$ dars, but in the summer it mar be reduced to $t^{1} / 2$ days. The pupa then changes to the adult, or beetle.

The adult of the tobacco flea beetle (fig 28) is rather small, measuring only about one-sixteenth of an inch in length. It is brown with two darker areas of rather indefinite size and shape on the wing covers.

The adults frequently emerge after showers, which moisten the surface soil and aid their exit. Heary driving rains are. howerer. 
detrimental to the beetles, this being especially true when they are present on small plants which offer little protection.

The beetles remain rather inactive for a period of about 24 hours after emergence, then begin feeding on the lower leaves which touch

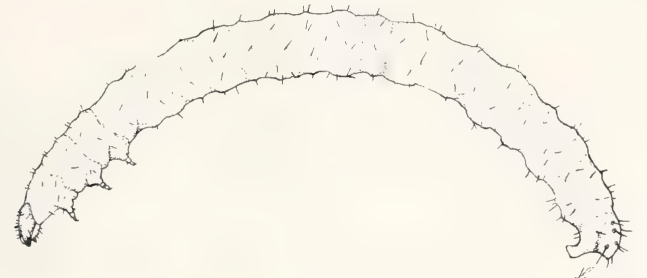

Figure 26.-Mature larva of the tobacco flea beetle, $\times 15$.

the ground. In most of this early feeding the beetles confine their eating to the lower leaf surface. In a short time, however, the feeding punctures go entirely through the leaf. The beetles remain on the lower leaves for 3 or 4 days and then gradually spread over the entire plant. In the case of sungrown tobacco the feeding is largely confined to the lower portion of the plant. In the case of shaded tobacco, however, the upper leaves are frequently punctured to a considerable extent, and even the bud leaves are sometimes fed upon. Under shade conditions there seems to be little choice between the upper and lower leaf surface, although in high tobacco there is apparently some slight preference for the upper surface.

\section{SEASONAL HISTORY AND HABITS}

The tobacco flea beetle passes the winter in the adult form. The insects find shelter under piles of leaves and trash and in the upper surface of the soil

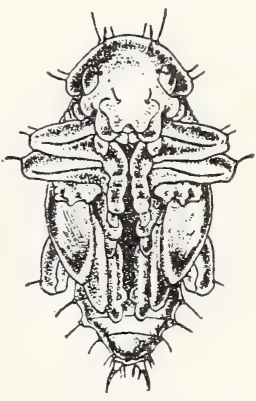

Figure 27.-Pupa of the tobacco flea beetle.

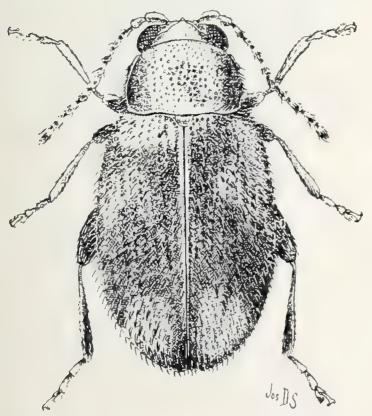

Figtre 28.-Arlult of the tobacco flea beetle, $\times 23$.

and often hibernate along the edges of woodland adjoining tobacco fields (fig. 29). The beetles doubtless hibernate in considerable numbers in the few tobacco fields where the stalks are allowed to remain undisturbed throughout the winter. In these situations they remain in a more or less dormant condition during the winter. In warm periods, however, the beetles become more active and may be found feeding in sheltered spots.

The beetles are usually first noticed early in the spring when the tobacco plants are beginning to appear in the seedbeds. They come from their winter fast with ravenous appetites and seek food immediately.

The first beetles to issue from hibernation in the spring may begin laying eggs in the plant beds while the plants are still small. 'The moist, sheltered beds furnish excellent breeding' places, and often produce large numbers of this insect. No doubt it 
occasionally happens that larrae, which feed on the roots, are carried on the plants from the beds to the fields.

Flea beetles begin to infest tobacco fields rery soon after the plants are set out. At first they are most numerous at the edges of the fields. but they gradually make their way toward the middle areas. After they have become well established on tobacco there appears to be no marked tendency for further morement unless they are disturbed.

The egg-laying period is apparently of rather short duration at this season of the rear, as the beetles usually begin to die off from natural causes during the first part of April.

There is an intervening period of from 2 to 3 weeks when rery few beetles are usually seen in the fields. Then the adult progeny of the orerwintered flea beetles usually appear in this region about

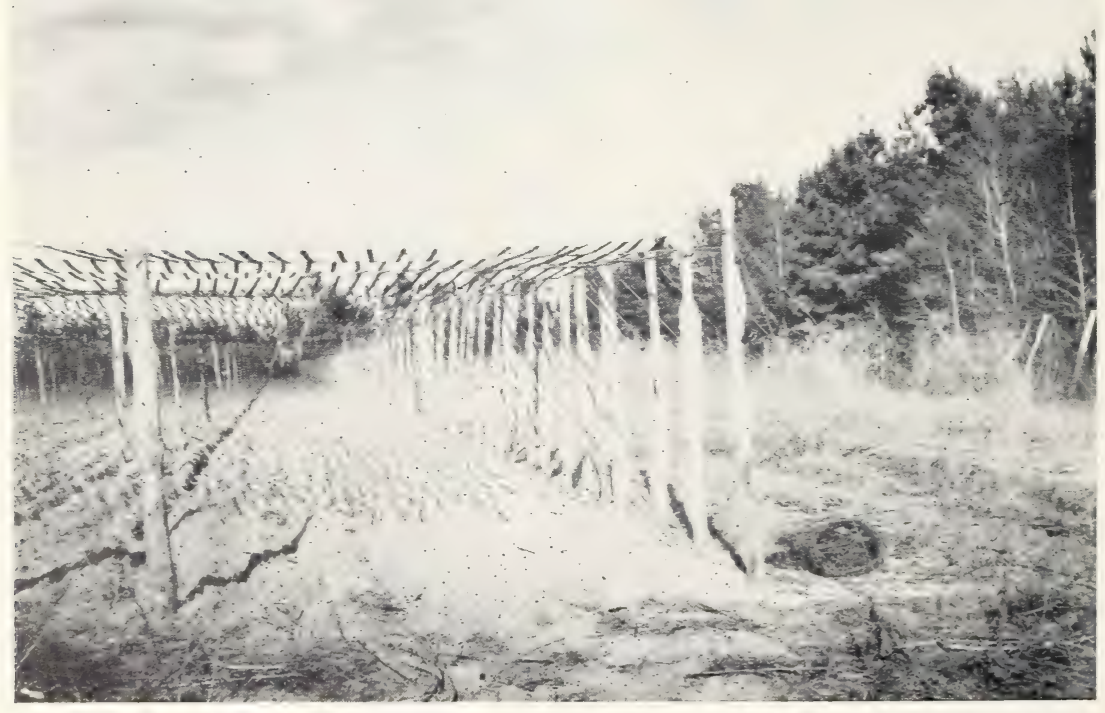

Frgtre 29.-Woodland adjoining a tobacco shade field. Flea beetle adults hibernate along the edges of such wooded areas.

the second week in Mar. The majority of them may appear at about the same time or ther mar continue to emerge orer a considerable period. Large numbers often emerge after showers which soften the upper soil sufficiently to allow free access to the surface.

After a feeding period of about 3 weeks these beetles begin to lay eggs. The incubation of these eggs and subsequent derelopment of the larrae are similar to those of the first generation. but may be accomplished in a much shorter time. Adults of the second generation usually appear about the time tobacco has reached maturity, and frequently cause much damage.

From this it is seen that the tobacco crop is attacked by the orerwintered brood and by two later broods of flea beetles. If farored by natural conditions, each generation brings about an enormous increase in the number of individuals. 
After the tobacco crop is harvested there may be additional generations which so overlap that it is impossible to tell them apart. During the late summer months the beetles become very scarce. Few eggs are deposited and still fewer young survive. A large number of the adults apparently die and the remainder show little activity.

\section{FOOD PLANTS}

Although tobacco is the preferred food plant of the tobacco flea beetle, numerous other wild and cultivated plants belonging to the same family (Solanaceae) are fed on to a moderate extent. Among these the most important are potato, tomato, eggplant, pepper, groundcherry, nightshade, horsenettle, and jimsonweed. In the absence of solanaceous plants the beetles will feed sparingly on various other wild and cultivated plants.

\section{CHARACTER OF THE INJURY}

The flea beetle injures tobacco by eating small irregular holes in the leaves (fig. 30). The insect seldom confines its feeding to any one portion of the leaf but usually feeds spasmodically over the entire leaf surface. As the holes are often made before the leaf has completed its growth, the size of the holes increases as the leaf grows, and the damage is accordingly increased.

In this region flea beetle injury is usually of economic importance only on tobacco that is raised for cigar wrappers, in which the injury consists in loss of quality. Even a few small holes in the leares depreciate the value of the product, as the percentage of wrappers that can be cut from them is reduced. In certain cases the leares may be so injured that no wrappers can be obtained from them, and the tobacco is thereby reduced to the filler grade with a rery heary loss in ralue.

\section{CONTROL MEASURES}

\section{CULTURAL CONTROL MEASURES}

Every possible means should be used to keep insect pests of tcbacco in this region in a continuous state of subjection. This applies especially to the tobacco flea beetle, which has caused heary losses 
to the wrapper crop in the past. Ill the methods of control. both direct and indirect, suggested in this circular should receire serious consideration, for ther have an important bearing on the problem.

Plant beds should be located as far as practicable from tobacco fields. The moist soil under the plants. which is not disturbed except by reeding, furnishes an excellent breeding place for the next generation of beetles. A rery slight infestation of a bed by orerwintered beetles can often produce a surprisingly large number in the next generation, which may attack the tobacco in any nearby field. If the bed is located at some distance, this danger is considerably lessened. Flea beetles on plant beds should be controlled by the methods previously described.

As the tobacco flea beetle feeds on and multiplies to a limited extent on a number of wild plants, all weeds in and around the edges of tobacco fields should be destroyed as far as possible.

One of the most important cultural methods of controlling the flea beetle is the complete destruction of all tobacco stalks and stumps immediately after the crop is harrested. The remoral of the main food supply at this time prevents continued breeding of the insect and is unfarorable for those individuals that enter hibernation.

THE APPICATION OF INSECTICIDES

While the feeding by the orerwintered beetles (fig. 31) in most instances causes little damage to the newly set plants in this region, the eggs produced by relatively few beetles are a potential menace to a wrapper-tobacco crop. For this reason it is a mise precantionary measure to apply an effective insecticide soon after the plants are set, even though very few beetles are in evidence (fig. 32).

A rery satisfactory control for flea beetles on tobacco is a dust containing 1 percent of rotenone derived from derris or cube root. These rotenone-bearing dusts kill flea beetles quickly and are harmless to tobacco plants. A disadrantage of the rotenorie dusts is the fact that ther exert no appreciable control on grasshoppers, which frequently attack tobacco. Grasshoppers may be controlled effectively, howerei. by means of the poisoned bait described on page 39 of this circular.

Commercially prepared dust containing 1 percent of rotenone may be obtained, or a home-mixed dust can be made by mixing 25 pounds of derris or cube porder (containing 4 percent of rotenone) with 75 pounds of sterilized tobacco dust as a diluent.

If the rotenone content of the derris or cube powder is greater or less than 4 percent, the proportion of the diluent must be raried accordingly. The powder should be of such a degree of fineness that not less than 90 percent of it will pass through a sieve having 200 meshes per linear inch, and all the material should pass through a sieve having 80 meshes per linear inch.

The quantity of dust applied during an application should be governed by the size of the tobacco plants. From the date the plants are set intil they are about 18 inches high a dosage of 3 to 5 poundper acre should be sufficient. whereas mature tobacco may require 8 to 10 pounds per acre. An efficient rotary duster capable of giving eren distribution should be used. Then the plants are not orer knee high the dust application is most effective when the nozzle of the dust gum is directer toward the foliage and in front of the operator (fig. 


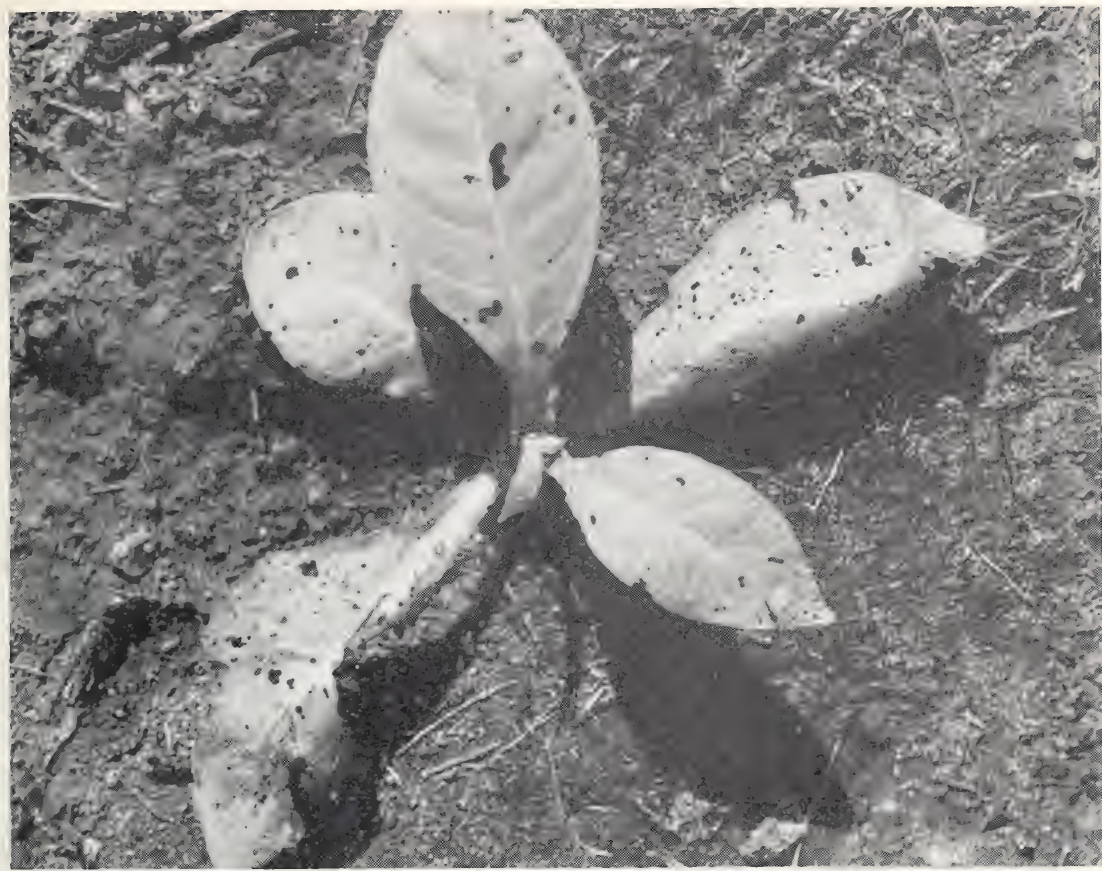

Figure 31.-A newly set tobacco plant showing the result of feeding by the flea beetle. The larger leaves on this plant are about 6 inches in length.

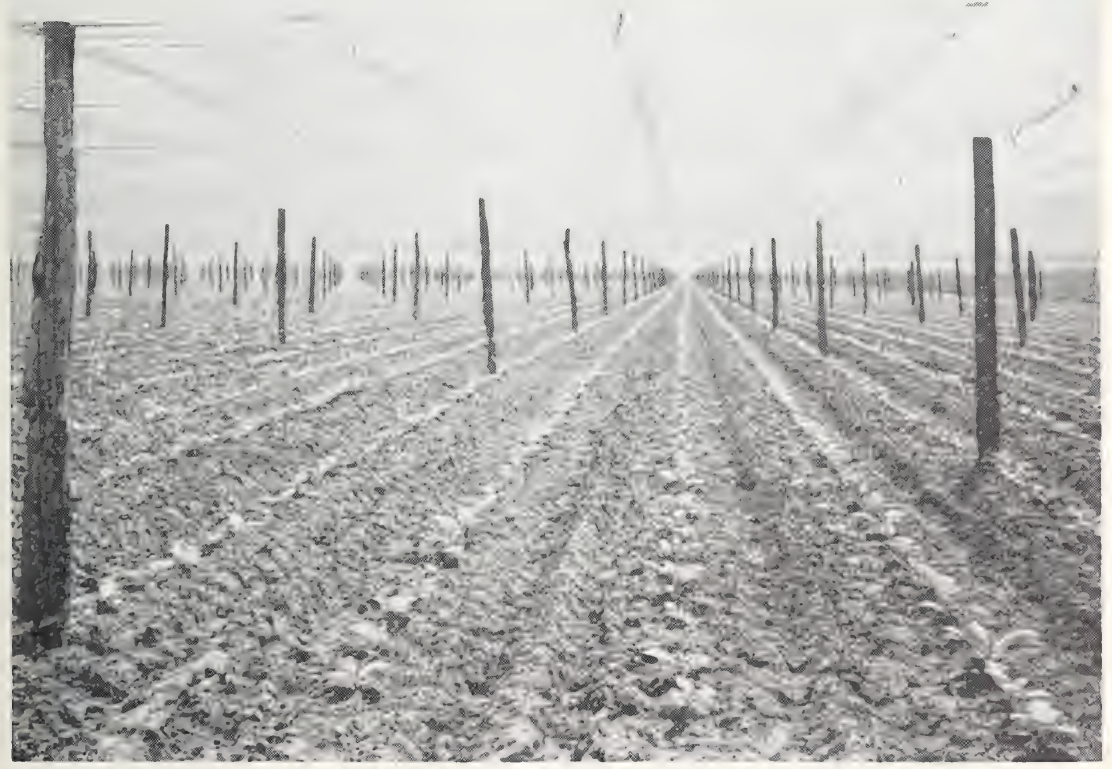

Futurs: 32.-A portion of a tobaten shade field showing newly set eigar-wrapler tobacco. This is the best time for controlling the flea beetle by the application of poison dusts, since only a reiatively few overwintered beetles are concentrated on a small amount of leaf surface. 
33). The dust cloud in this case will not rise sufficiently to cause discomfort to the operator. When the plants are larger it is impossible to corer all the foliage by a direct application. Ender these conditions the dust-gun nozzle is held in the center of the space between the tobacco rows and the dust allowed to drift onto the leares. In high tobacco the operator should aroid the dust as much as possible by directing the nozzle to the rear. W'hen large acreages are being treated in this manner the operators of several dusters may walk abreast to avoid the dust cloud (fig. 34).

The frequency and the number of applications necessary to protect a tobacco crop will depend mainly on the abundance of beetles present during the growing season. Flea beetle infestations vary greatly from year to year and from one field to another. From the

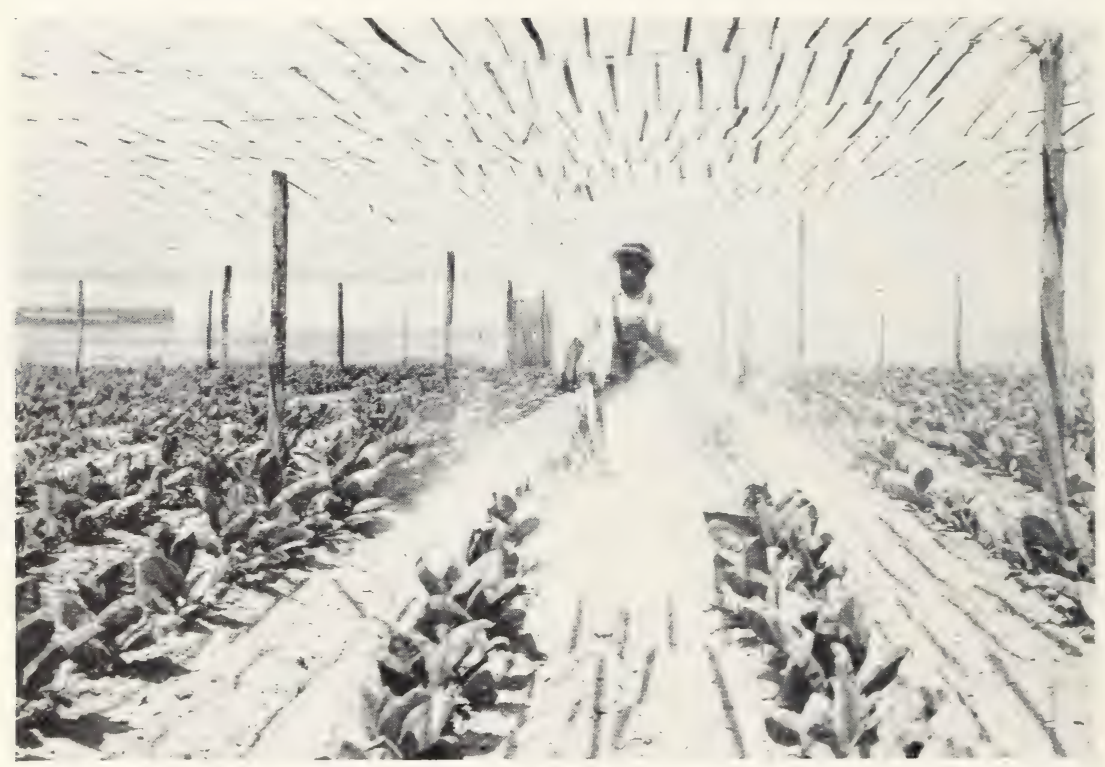

FIGLRE 33.-Ajplring dust to shade-grown tobacco that is less than knee high, the nozzle of the dust gun being directed toward the foliage and in front of the operator.

information arailable at the present time it appear's that under the usual conditions about one application a week will give sufficient protection to a crop. Rotenone-bearing dusts are not effective in the shade-tobacco area for a rery long period. Under the most farorable conditions it appears that the effectiveness of an application will be limited to about 3 days. Observations indicate. in general, that frequent. light applications made throughout the growing season exert much more satisfactory control than a small number of relatively heavy applications.

Applications of barium fluosilicate may be made to control flea beetles on newly set tobacco. This poison is effective against both flea beetle- and gra-hopper's. and may be used to control joint outbreaks of these two species on roung shade-grown tobacco. To obtain an even distribution of the poison it must be mixed with a 
free-flowing carrier. Finely ground, sterilized tobacco dust has been found satisfactory for this purpose. The barium fluosilicate and the tobacco dust are mixed in the proportions of 8 parts by weight of the poison to 2 parts of tobacco dust. Applications of the mixture should be made at the rate of from 4 to 6 pounds per acre. The poison mixture when evenly applied at this rate should be safe on newly set tobacco plants. The use of this insecticide on large tobacco is not recommended, however, since it may cause burning or discoloration of the leaves under certain weather conditions.

Paris green in the dust form may be used to control flea beetles on newly set tobacco. While the poison is quite toxic to the insect, it

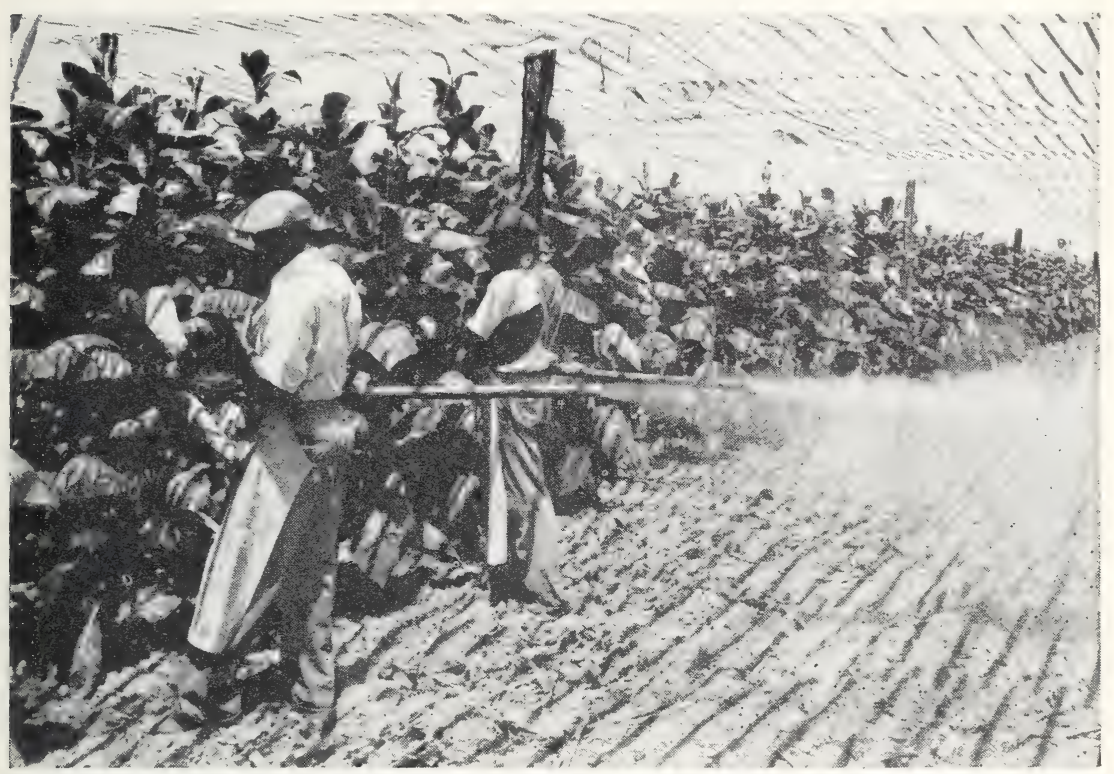

Figure 34.-Dust-gun operators walking abreast in order to avoid the dust cloud, when applying poison to tall, cigar-wrapper tobacco. The men are about to enter the rows of tobacco.

must be applied very lightly and with extreme caution or burning of the plants will result.

CAUTION : Operators of hand dusters should protect the body with aprons (fig. 34) when applying paris green, rotenone dusts, or barium fluosilicate.

\section{Cutworms}

Although cutworms are considered one of the minor tobacco pests in the South, they are present, under certain conditions, in sufficient numbers to cause serious damage. With the exception of the damage produced by climbing forms, the injury invariably occurs in the spring in plant beds or on newly set tobacco. The injury consists in the cutting off of young plants near the surface of the ground and in the devouring of the leaves (fig. 35). The resetting of plants adds to the expense of growing the crop and is frequently unsatis- 
factory. If resetting of a broken stand is delayed longer than a 3- or t-day interval, the reset plants seldom make a normal girowth and mature later than the original setting.

Since cutworms attack sun-grown and shade-grown tobaceo in the same manner, the control measures outlined apply equally to both.

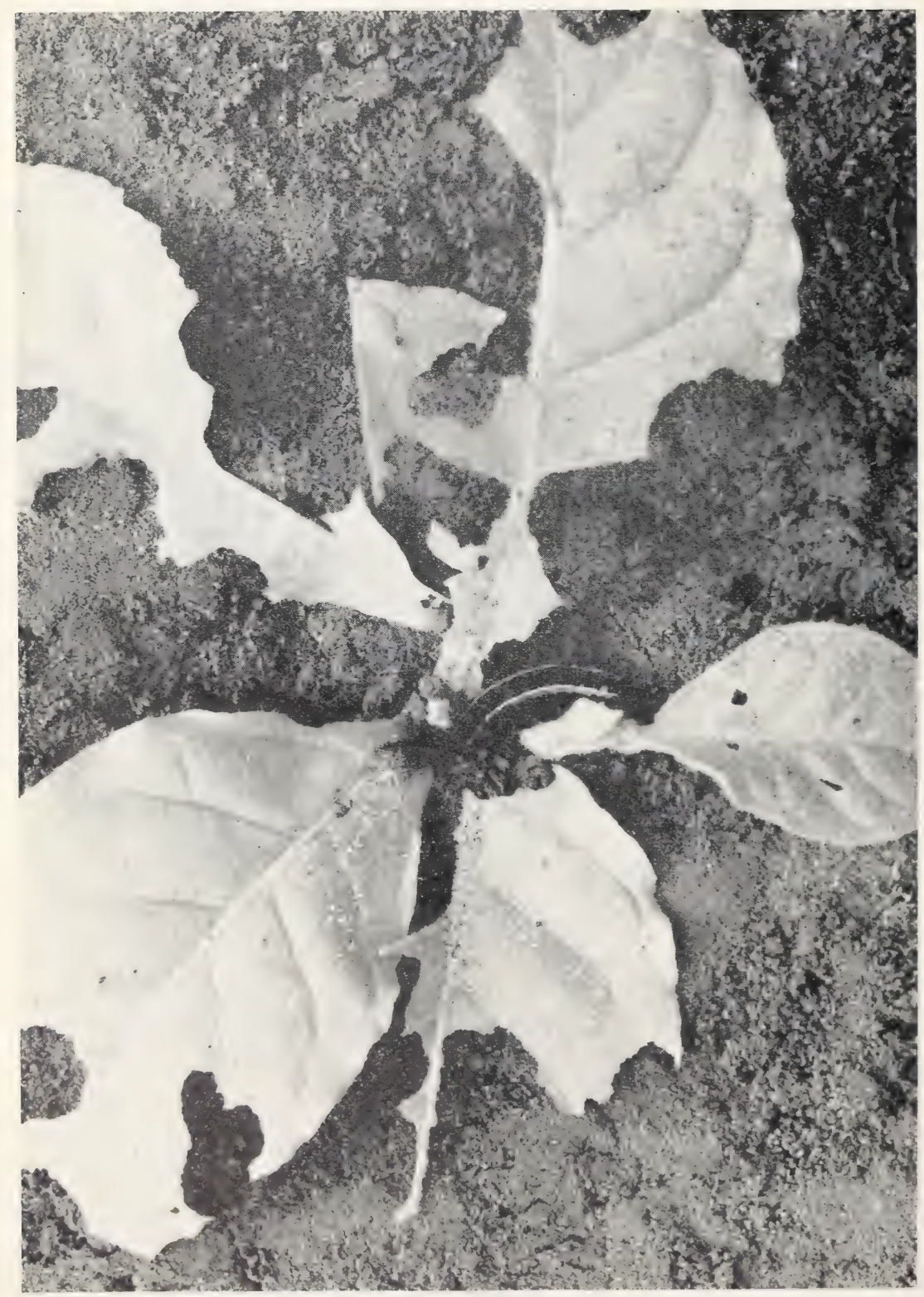

Figtre 35.-A cutworm feerling on a newly set, shade-grown tobacco plant. 


\section{LIFE HISTORY AND HABITS}

Although several species of cutworms attack tobacco in this region, they are very much alike in general appearance and habits. The common forms are the brownish-colored, granulate cutworm (Feltia subterranea (F.) (= annexa (Treit.))), the black cutworm (Agrotis ypsiton (Rott.)), and the pale-sided cutworm (Agrotis malefida Guen.). Other species which assume the climbing habit and occasionally injure the leaves of tall tobacco will receive mention in another portion of this circular (p. 48).

'The granulate cutworms constitute about three-fourths of the total number of the cutworms that injure young tobacco in this region. The life of these insects is divided into four distinct stages, the egg, the caterpillar, or larva, the pupa, or resting stage, and the adult, which is a small, inconspicuous, brownish-gray month. Farther north these cutworms hibernate during the cold winter months. In this region, however, the moths and larvae are active throughout the entire year except in the coldest winter weather.

Several hundred eggs may be deposited by each female moth. They are laid on the foliage of green vegetation (fig. 36) in cultivated fields. The length of time required for the eggs to hatch may range from 2 to 6 days during the summer months, but during cold weather the hatching period may be considerably longer.

The young larvae begin to feed immediately after hatching and grow rapidly if conditions are favorable. They are general feeders and attack practically all vegetable crops as well as tobacco. Feeding takes place mainly at night, while during the day the larvae are usually found in the soil

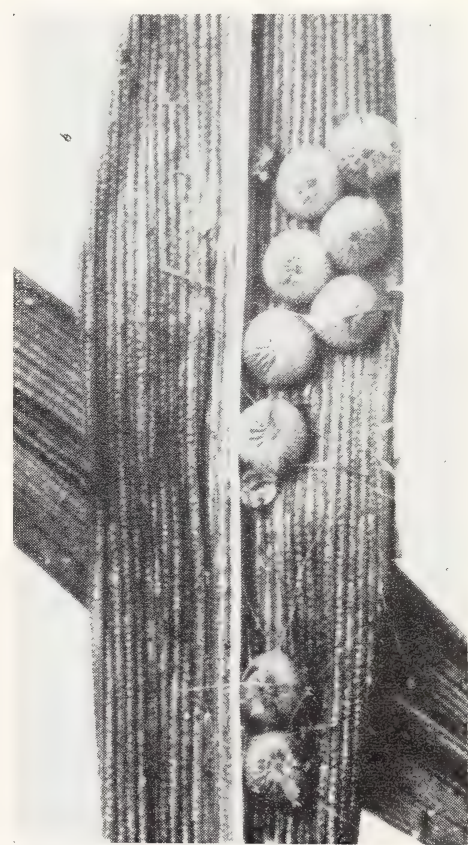

Figure 36.-Eiggs of the granulate cutworm deposited on a grass blade. near the plant on which they fed during the previous night. This species can live on dry vegetation when no green food is available. While the cutting off of newly set plants is the most serious form of injury, the larvae frequently injure young tobacco by feeding on the leaves that lie near the ground. 'The length of the larval stage appears to be governed by the prevailing temperatures. Late in the spring and during the summer months it has been found to require about 30 days in this locality.

When the cutworm is fully grown it is as large around as a lead pencil and from 1 to 11/2 inches long (fig. 37). An earthen cell is then formed about 2 inches below the surface of the soil, and in this the larva transforms to the pupa (fig. 38), or resting stage. This 
resting stage usually requires about 12 days in hot weather, but the period may be prolonged in the spring and winter months.

At the end of the pupal stage the adult, or moth (fig. 39), emerges and the life cycle is complete. There appear to be five or six generations a year in this locality which so overlap that it is impossible to tell them apart.

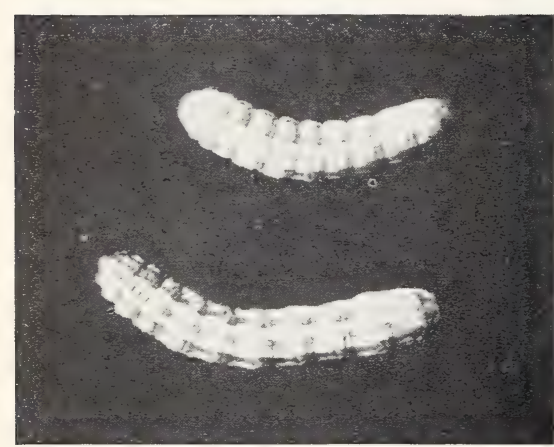

Figure 37.-Mature larvae of the granulate cutworm, about natural size.

\section{CONTROL MEASURES}

\section{CULTURAL PRACTICES}

It has been observed for many years in this region that cutworms are most numerous on land that has been covered previously with green vegetation such as pasturage, rye, oats, or other cover crop. This vegetation apparently attracts the moths during the period of egg laying and afterward serves as food for the worms. Plowing under all vegetation a short time before setting tobacco does not rid the land of cutworms, as several species can develop on dead regetation, while other forms can survive for several weeks without food. If, however, the land has been kept cleanly cultivated for a period of at least 60 days before setting the tobacco plants, little trouble from cutworms is usually experienced. During this interval there is no vegetation to attract the moths for egg laying and the cutworms already in the soil continue their development, so that by the time tobacco is set out the great majority of the cutworms have passed into the harmless pupal stage. While the practice of keeping land free of green vegetation during the winter and spring months will reduce the number of cutworms in tobacco fields, this recommendation should not be followed if it conflicts seriously with a fertility or disease-control program.

THE USE OF POISONED BAIT

The number of cutworms in the soil may be greatly reduced by the use of poisoned bait. The following bait formula is recommended:

Figtre 38.-Pupae of the granulate cutworm: $d$. Dorsal riew: $B$, ventral view. $\times 3$.

Pounds

Wheat bran 50

Paris green 1 
Baits containing a greater proportion of paris green than the recommended formula frequently exert less control, as relatively large quantities of paris green are rather repellent to cutworms. Sirup or molasses is frequently used in cutworm bait, but they appear to be of little value in this region, except to aid in retaining the moisture in the bait.

The bran and poison should be mixed thoroughly in the dry state and just enough water should then be added to make a mixture that, when pressed together in the hand and released, will fall apart with a crumbly consistency. Small quantities of the bait may be prepared in a large tub, while larger quantities can be mixed with a garden hoe or shovel in a tight-bottomed box or wagon body (fig. 40). Care should be taken by persons mixing the bait to inhale as little of the paris green dust as possible.

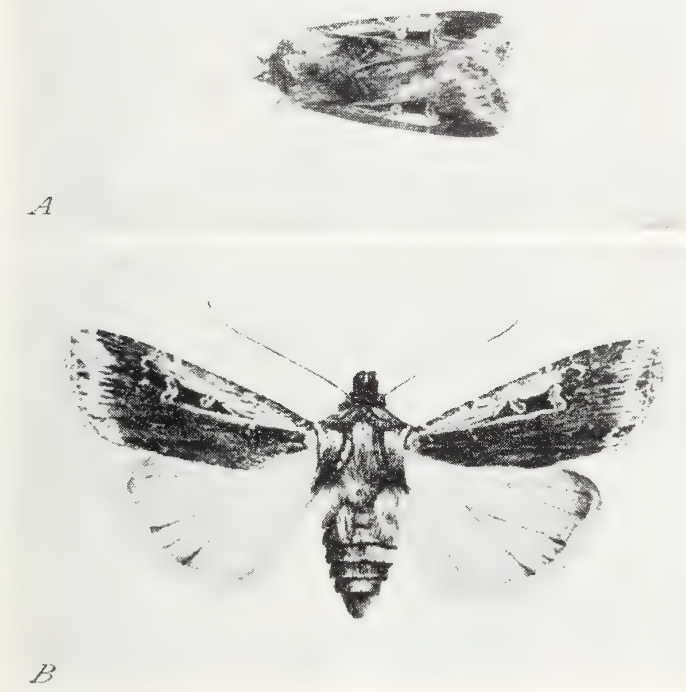

Figure 39.-Adult of the granulate cutworm: A, In the natural resting position with the wings folded; $B$, with the wings spread. $\times 11 / 4$.

After the land has been put in condition for setting the plants, the bait should be broadcast over the field at the rate of about 20 pounds, dry weight, per acre. The application should be made late in the afternoon, preferably about sunset, and several days before setting the plants. If the land is heavily infested with larvae, two applications of the bait, with a 2 - or 3-day interval between the applications, may be necessary to produce effective control. If a heavy rain follows a bait application, it will be ineffective, and the application should be repeated.

The same bait may be used if the plants are attacked after setting, but it should be scattered on the ground between the rows, care being taken that lumps of the material do not fall upon the plants, as burning of the foliage will result. When the poisoned bait is applied after setting, however, it frequently happens that a considerable 
number of plants will be destroyed before the infestation can be brought under control. Applications made befone the plants are set in the field appear to be the more effective.

Cutworms sometimes assume the armyworm habit and migrate into a tobacco field from outside areas. Under these conditions the bait should be spread in a protecting barrier around the tobacco field.

OTHER CONTROL METHODS

In cases of serious infestations, hand picking of larrae is sometimes employed. This work can best be done early in the morning. when they are most easily located.

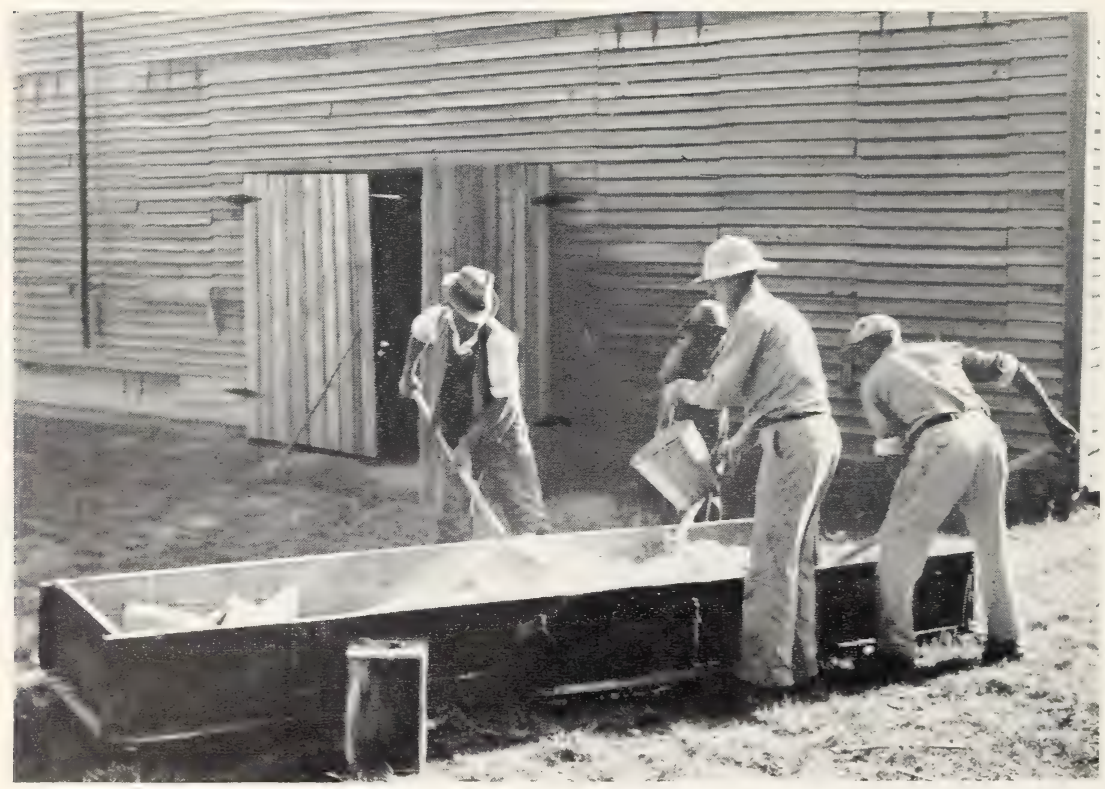

FIgtre 40.-Mixing cutworm bait in a wagon body. This or similar trpes of boxes are usually arailable and can be used as mixing troughs when large quantities of bait are to be prepared.

In this cigar-wrapper district, applications of paris green or barium fluosilicate for the control of tobacco flea beetles are often made to the crop soon after setting. These applications assist in the control of cutworms. The corn meal and lead arsenate mixture employed to control budworms also assists rery materially in controlling cutworm infestations on newly set plants. The cutworm control is most effective when the applications are made with shaker (ans which deposit the poisoned meal on the plant foliage and on the ground about the base of the stalk.

\section{GRASSHOPPERS}

Grasshoppers are pests of considerable importance in fields of sun-grown tobacco and in shaded tobacco fields. These insects breed in greatest abundance in uncultirated grassland, but frequently 


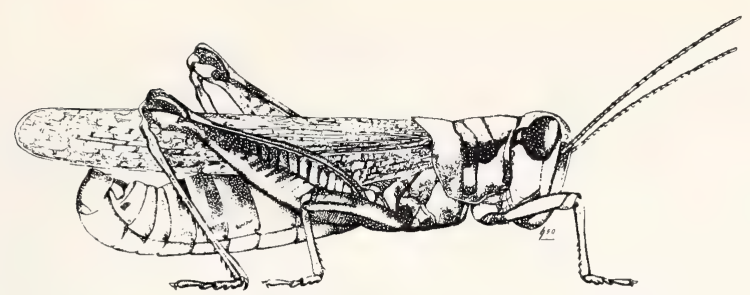

Figure 41.-The southern red-legged grasshopper.

move into cultivated crops to obtain a more favorable food supply. Grasshoppers with short antennae, the southern red-legged grasshopper (Melanoplus femur-rubrum propinquus Scudd.) (fig. 41) and the lesser migratory grasshopper (Melanoplus mexicanus Saussure),

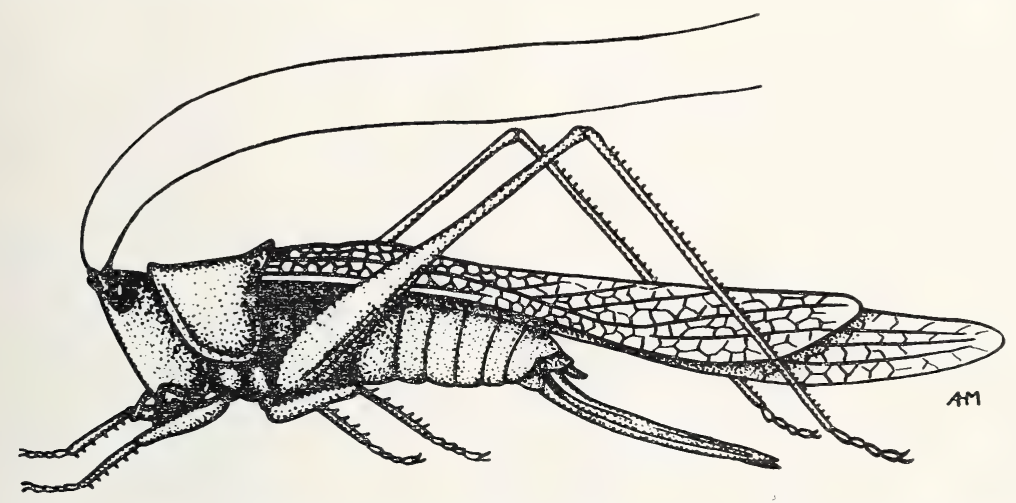

Figure 42.- The long-horned grasshopper, about $\times 5$. This insect sometimes causes damage in tall tobacco.

are the most abundant forms in tobacco fields, while the slender, greenish-colored grasshoppers with long antennae (Conocephalus sp.) (fig. 42) are sometimes injurious in high tobacco. The large American grasshopper (Schistocerca americana (Drury)) (fig. 43) occasionally causes some injury to this crop.

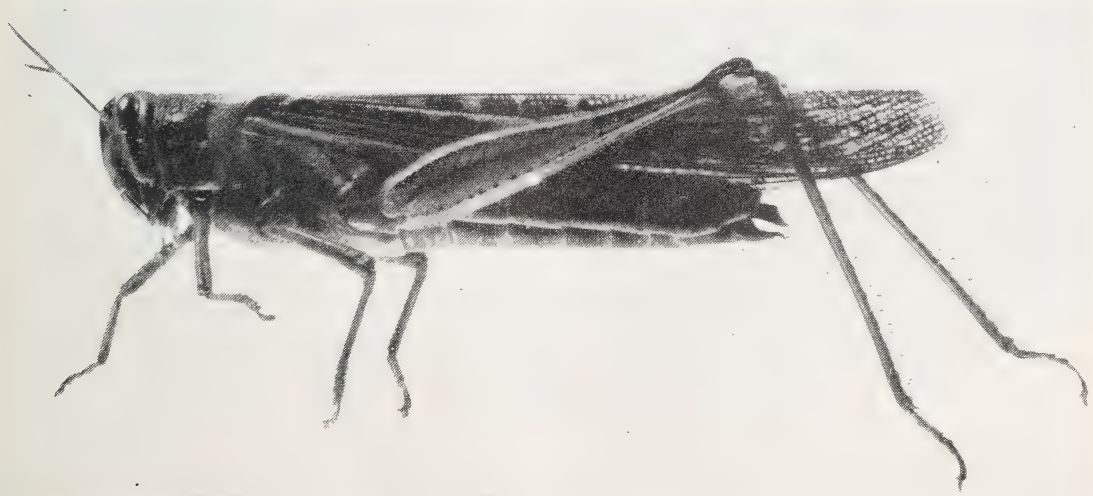

Figure 43.-The American grasshopper (Schistocerca americana), $\times 1 \frac{1}{1}$. This grasshopper occasionally attacks cigar tobaccos. 
The two species of Melanoplus resemble each other very closely, and their life history and habits do not appear to differ in any material respects. The spring emergence period of these grasshoppers usually corresponds rather closely with the tobacco-setting season in this region, but emergence may continue to a limited extent during a 3 -week period, especially if the weather is wet and cold.

Under farorable weather conditions they feed on any available regetation and grow rapidly. They shed their skins at rarying intervals, and the majority reach the adult stage about the first of June. These adults deposit eggs in the soil, but the second brood of young grasshoppers fortunately arrives too late in the season to cause much injury to the tobacco crop.

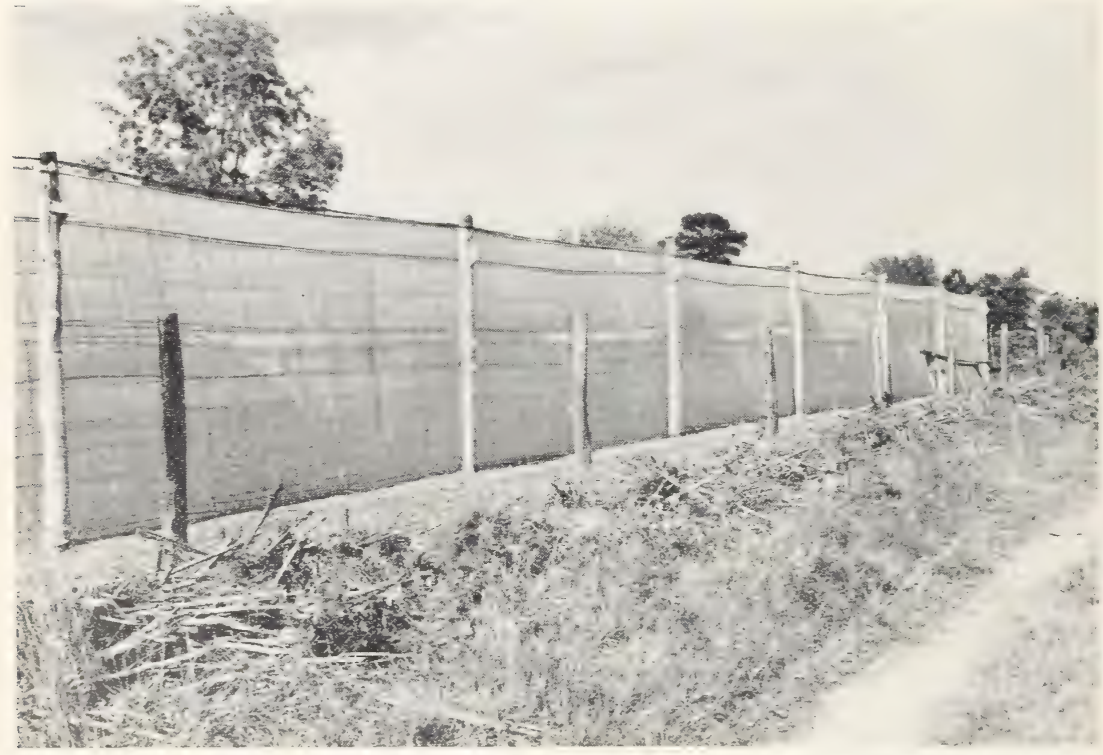

FigLre 44.-A portion of the side wall of a tobacco shade field, showing how the cloth should be brought closely to the ground and held in place to prevent the entrance of grasshoppers from beneath.

Adults and immature stages can be found to a rery limited extent late in the fall and during the winter months in this region, but the insects spend the winter mainly in the egg stage in the ground.

\section{CONTROL IN TOBACCO SHADE FIELDS}

The cloth tops and side walls of tobacco shade fields give a great amount of protection from grasshoppers. Newly hatched stages are so small. howerer, that they may work their way through a single layer of the ordinary, coarse-mesh shade cloth. Side walls consisting of double or triple layers of shate cloth serve as fairly effective barriers against eren the -mallest gras-hoppers. To obtain the greatest possible benefit from the -ide walls the lower edges of these walls must be fastened closely to the ground to keep the insects from gaining access from beneath (fig. $4 t$ ). Is previously stated. raising the walls to permit the entrance of wagons and farm implements is bad practice. 
While grasshoppers are found in greatest abundance in uncultivated grassland, sufficient numbers may emerge inside tobacco shade fields to necessitate control measures. This is frequently the case even when the soil has been well plowed and harrowed during the preceding winter.

Control is accomplished most easily and economically when the insects are small and before the tobacco plants have attained much growth. One of the most effective and cheapest means of controlling grasshoppers is the use of poisoned-bran bait such as the following:

Wheat bran 50 pounds

Paris green $21 / 2$ do

Cheap sirup, or preferably blackstrap molasses

Water to moisten.

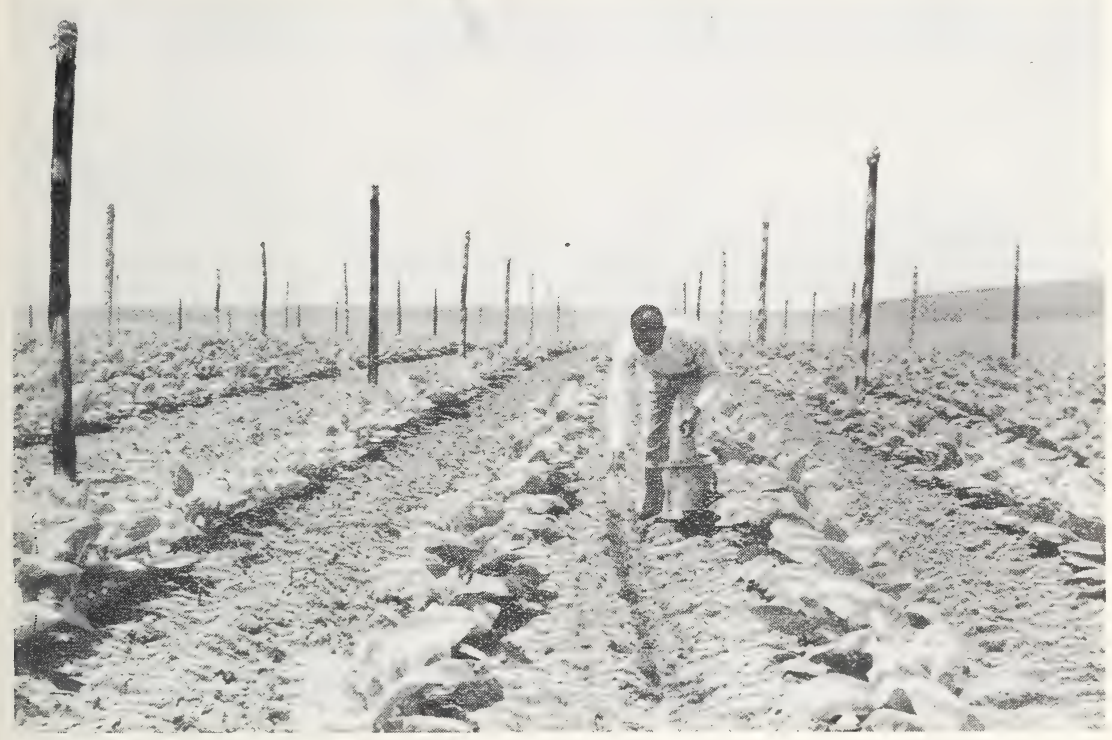

Figure 45.-Applying poisoned bait between the rows of tobacco plants for the control of grasshoppers. Care must be exercised to avoid scattering any of the mixture on the plants, otherwise serious burning of the foliage will result.

The bran and paris green should be mixed thoroughly in the dry state, after which the water and sirup should be added. Small quantities of the bait may be prepared in a large tub, and larger quantities can be mixed in containers of greater capacity. The mixture should be damp but not wet. Persons mixing the bait should observe all precautionary measures regarding the handling of paris green and should not breathe excessive quantities of the dry material.

The poisoned bait should be scattered thinly over the infested shade fields at the rate of about 10 pounds, dry weight, per acre. If the tobacco is newly set, the bait may be broadcast over the land without detriment to the plants, provided it is scattered evenly. If the plants have begun to grow, the mixture should be applied in the space between the rows (fig. 45). It will cause burning if it is thrown onto the foliage of large plants. To obtain the greatest benefit from the 
poison mixture, the ground on which it is scattered should be left uncultirated for at least 2 days after an application is made, as the bait is inaccessible to the grasshoppers when covered with dirt.

Owing to the rush of spring work it sometimes happens that the transplanting of tobacco plants into the shades precedes the construction of the shade walls. Without these protecting barrier's grasshoppers frequently enter shade fields from outside areas. In instances where grassland adjoins shade fields (fig. 46) this is nearly always the case.

Under these conditions the bait should be scattered in a wide strip around the borders of the shades as well as within the shade-field areas. Applying poisoned bait to infested grassland immediately adjacent to tobacco shades is a worthwhile practice even when the

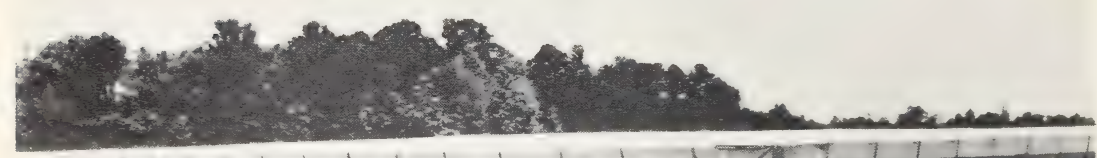

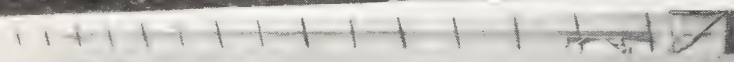

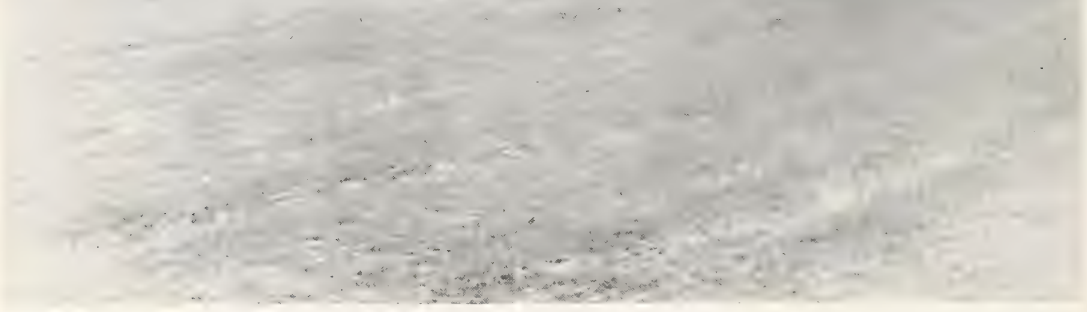

FIGURE 46.-An area of grassland adjoining a tobacco shade field. Fields of this trpe are farorable breeding grounds for large numbers of grasshopper's.

walls are in place, as a certain number of small grasshopper's inrariably work their way inside.

The poisoned bait will kill a large percentage of the insects present at the time of application. They do not die immediately after eating the bait but continue to succumb over a period of several days. The dead gras-hoppers are rather difficult to find. especially if they are small. immature forms. Frequently ther are torn apart and carried away by ants. The results of a bait application should therefore be determined by the absence of live grashoppers rather than by the numbers of dead indiriduals observed.

The bait should be applied by preference during warm. pleasant weather while the insect- are actively feeding. If the weather is very hot and dry the bait particles wili become hard and mattractive after a few hours. Ender these conditions. 2 quarts of low-girade, crlinder lubricating oil are sometimes added to 50 pounds of the bran mixture. Bait containing oil not only scatters more easily 
than the ordinary bait but remains soft and apparently more palatable over a longer period.

The number of poisoned-bait applications necessary in a shade field will depend on the degree of the infestation and on the length of the emergence period. Under the usual conditions one or two applications are sufficient to rid a shade field of these pests. If emergence continues over a considerable period, as many as four applications are sometimes necessary. If a heavy rain immediately follows an application of the bait, it will be ineffective and should be repeated.

Grasshoppers may be controlled very effectively on newly set tobacco by applications of barium fluosilicate in the dust form. This poison is also effective against flea beetles and may be used for controlling joint outbreaks of these two species of insects on young shade-grown tobacco as described on page 30 of this circular.

\section{CONTROL IN OPEN TOBACCO FIELDS}

Controlling grasshoppers in open tobacco fields is a more difficult task than within walled shade fields. Fortunately insect feeding on tobacco grown for cigar filler or binder is of less importance than on tobacco to be used for cigar wrappers. Heavy infestations of grasshoppers, however, may cause considerable damage to the filler and binder types. Such infestations can be greatly reduced at small expense by applications of the poisoned-bran bait. The bait should be scattered over the infested fields as recommended for shade-grown tobacco. If grasshoppers are coming into tobacco fields from surrounding fields, the bait should also be scattered over a 100-yard-wide strip of these fields next to the tobacco. When grasshoppers are very abundant about three applications may be needed. An attempt should be made to control the insects while they are small and before the tobacco has made much growth.

As a precautionary measure it is advisable to keep poultry out of all fields where the poisoned bait is used.

\section{DESTRUCTION OF GRASSHOPPER EGGS}

Late in the fall or during the winter months all tobacco land should be thoroughly plowed or disked to prevent, as far as possible, spring emergence of young grasshoppers. Grassy borders and nearby roadsides should also receive attention. Since the egg pods are usually found in the first 2 inches of surface soil, the ground should be plowed to a depth of at least 5 inches. The main object of plowing is to bury the eggs so deeply that the young grasshoppers are unable to make their way to the surface. Eggs that may be brought to the surface by cultivation will be exposed to the unfavorable drying action of the sunshine and wind, and to the attacks of their natural enemies. While winter cultivation will not destroy all the eggs or young grasshoppers present in the ground, this practice will assist materially in reducing the numbers of these pests.

\section{The Tobacco Thrips}

The tobacco thrips (Frankliniella fusca (Hinds)) causes considerable injury to cigar-wrapper tobaceo during abnormally dry growing 
seasons. These insects feed also upon sun-grown types of tobacco but cause them no appreciable commercial injury.

Within the Georgia-Florida producing region the severity and extent of thrips damage on wrapper tobacco has varied greatly from year to year, depending mainly on climatic conditions. Certain years have stood out prominently as "thrips years," while during the intervening seasons the insect has caused little damage.

\section{DESCRIPTION AND HABITS}

The adult tobacco thrips (fig. 47) is a minute, brownish-colored insect about one twenty-fifth of an inch in length. Some of these insects have wings which apparently are seldom used, while others possess only short wing pads. During warm, dry weather the adults spend most of their time on the upper surfaces of tobacco leares, being found usually in the depressions of the reins, where they do most of their feeding:

Adult females begin to deposit eggs soon after they have become established on the tobacco plants.

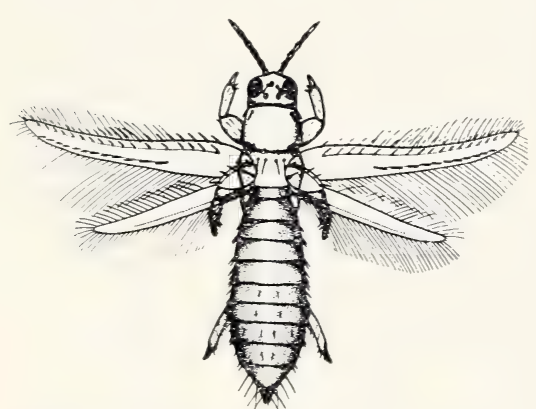

Figcre 47.-Adult of the tobacco thrips, $\times 32$.
The eggs are deposited in the epidermis, usually of the upper surface of the leaf. The incubation period during May, June, and July in the southern districts requires an average period of about $41 / 2$ days.

Newly emerged larvae are almost colorless and difficult to discern, but after they have fed they become yellowish and are more easily detected. They crawl about both surfaces of the tobacco leaves but the greater number are found on the upper surfaces.

The larval stage is followed by nonfeeding prepupal and pupal stages. Both these stages are spent on the leaf in a semiquiescent condition, and the lower surface seems to be preferred at this time. The total derelopmental period for the immature stages of the insect during the spring months arerages about 13 days.

$\mathrm{B}_{\mathrm{r}}$ the first week in May many individuals of the first generation have completed their development, although overwintered females are usually still emerging at this time. Orerlapping broods then follow one another throughout the tobacco-groming season. From the lower leares the thrips gradually ascend to the leares above, and the height which they attain depends mainly upon the climatic conditions. In seasons with abundant rainfall the limited number of individuals that survive confine their attacks mainly to the lower leares, while in extremely dry seasons the heary infestations spread upward to the highest leaves on the plants. Six or seren generations may attack the tobacco crop during its growing period.

The tobacco thrips feeds on many plants, both wild and cultivated. While it is mainly a foliage feeder, it is found also in the blooms of many plants, especially the legumes. As tobacco set on newly cleared land becomes immediately infested with this species, it is evident that 
the insect lives on numerous wild plants indigenous to uncultivated fields and woodlands. The most likely host plants for breeding sources are tobacco, peanuts, cocklebur, beggarweed, Gnaphalium sp., and several native grasses.

The tobacco thrips passes the winter in the adult form, and can be found in limited numbers on weeds and grasses throughout the winter months. The insects are found also in a semiquiescent condition in such protected places as the bases of sods and sheaths of grasses. The majority apparently hibernate in the surface soil in close proximity to their last feeding place.

\section{CHARACTER OF THE INJURY}

The injury caused by thrips on cigar-wrapper tobacco is known as "white vein," because of the whitened and silvered appearance of the veins (fig. 48). While the veins themselves may be bleached to a certain extent, the discoloration is due mainly to the injured tissue immediately adjacent to the midvein, the lateral veins, and the veinlets. This injury, which is produced by the feeding of the larvae and adults, occurs on the upper surface of the leaf. It is quite common on the outer marginal areas near the tip, which, unfortunately, are the most valuable portions for wrapper purposes. The insects, feeding in a very hurried and energetic manner, rasp open the outer tissues and remove the cell contents. The injured tissues later become shrunken and take on the characteristic silvered appearance when cured. Cigars wrapped with noticeably affected leaves have an undesirable appearance.

\section{CONTROL}

While control measures for the tobacco thrips are unnecessary during most seasons, safe and efficient remedial methods would be of benefit during occasional severe outbreaks. Unfortunately no entirely satisfactory methods are yet available.

SPRAY APPLICATIONS

A spray which has given a moderate degree of control under both experimental and commercial conditions consists of $11 / 2$ pounds of 40-percent nicotine sulfate by weight and 6 pounds of laundry soap to 100 gallons of water. In field experiments this spray killed about 86 percent of the adults and a somewhat higher percentage of immature individuals that were thoroughly wetted with the material. Under actual field spraying conditions, however, many escape the spray and the mortality is much lower. The eggs, which are protected from the spray within the leaf tissues, are also a source of reinfestation.

The nicotine sulfate and soap spray has been applied extensively to shade-grown tobacco, and only slight foliage injury has followed its use. The spraying of tobacco buds that have had the usual applications of lead arsenate and corn meal for budworm control involves some slight risk of burning, and it is evident that the spray should be directed away from the buds as much as possible.

While knapsack sprayers (fig. 49) may be utilized with some success in tobacco spraying, their operation on large acreages is ex- 
tremely laborious, and rather poor applications frequently attend their use. A high, two-wheeled cart equipped with gasoline spray pump and nozzle boom (fig. 50) has been found fairly satisfactory.

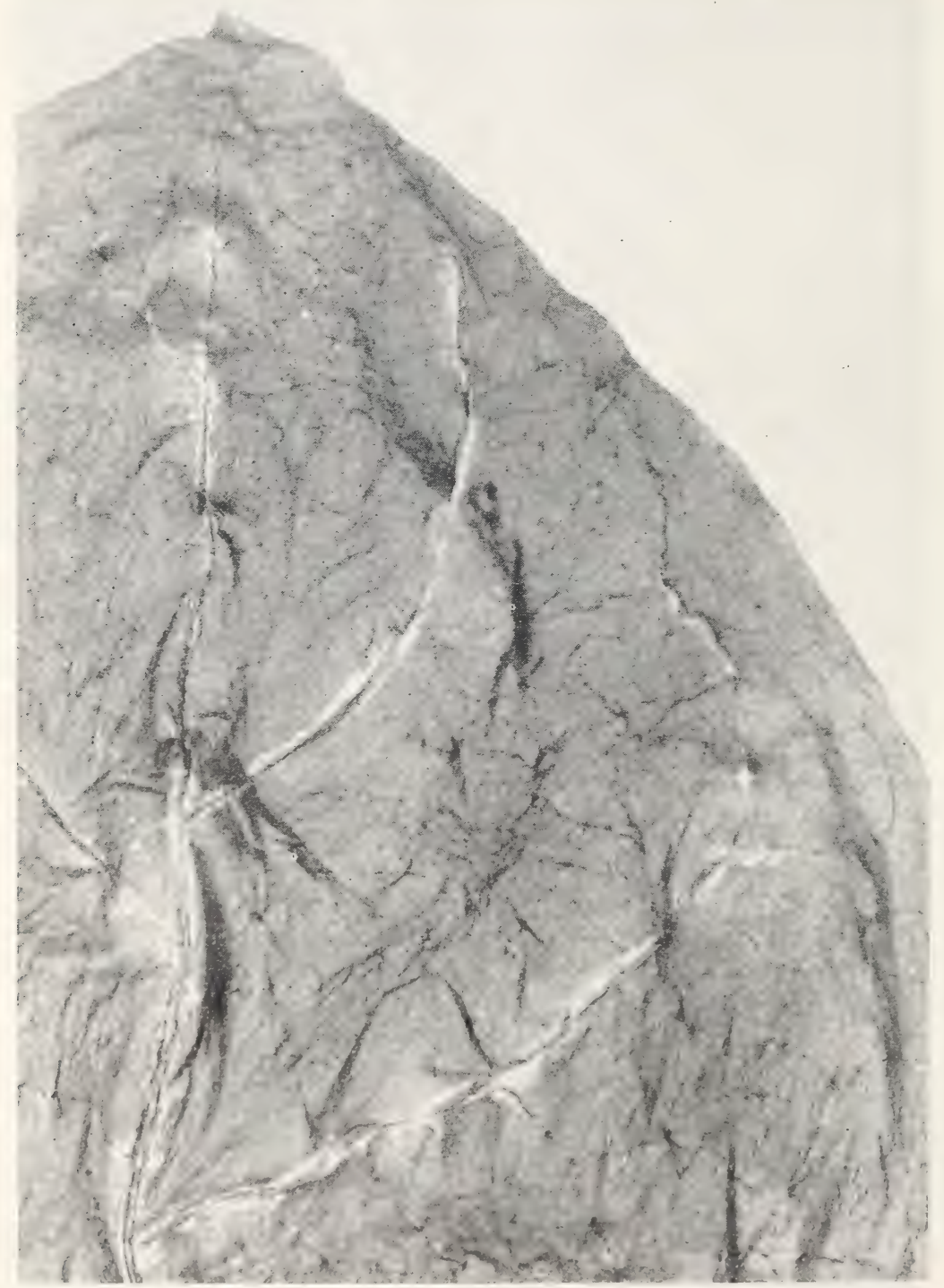

Figrae th.- I portion of a cured tobacro leaf of the cigar-wrapler type, showing the typical "white veins" caused by the feeding of the tobacco thrips. Cigars wrapled with such leaves have an undesirable appearance.

although it callses some damage when turning at the ends of the tobacco rows. As this trpe of sprayer straddles one row of tobacco. it cannot be used after the plants have been tied up to the top of the sharle structure. Spraying after this time appears to be rather im- 


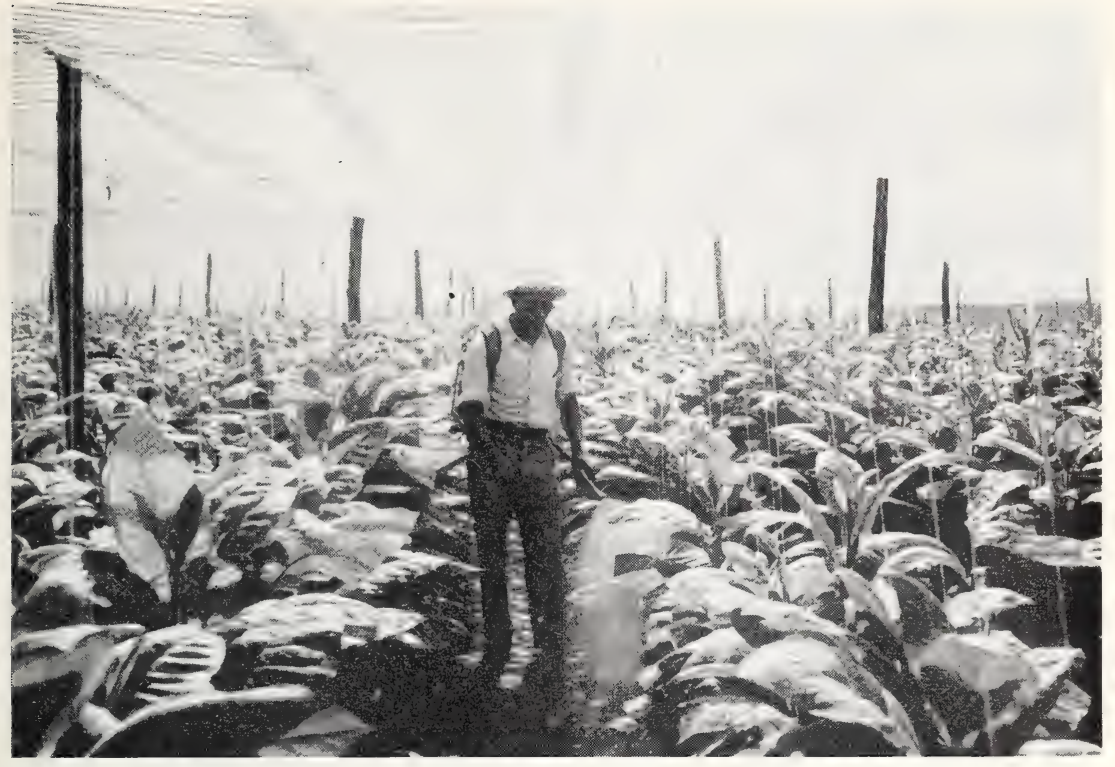

Figure 49.-Spraying shade-grown tobacco with a knapsack sprayer for the control of the tobacco thrips. This method is extremely laborious and does not always result in an even application of the spray.

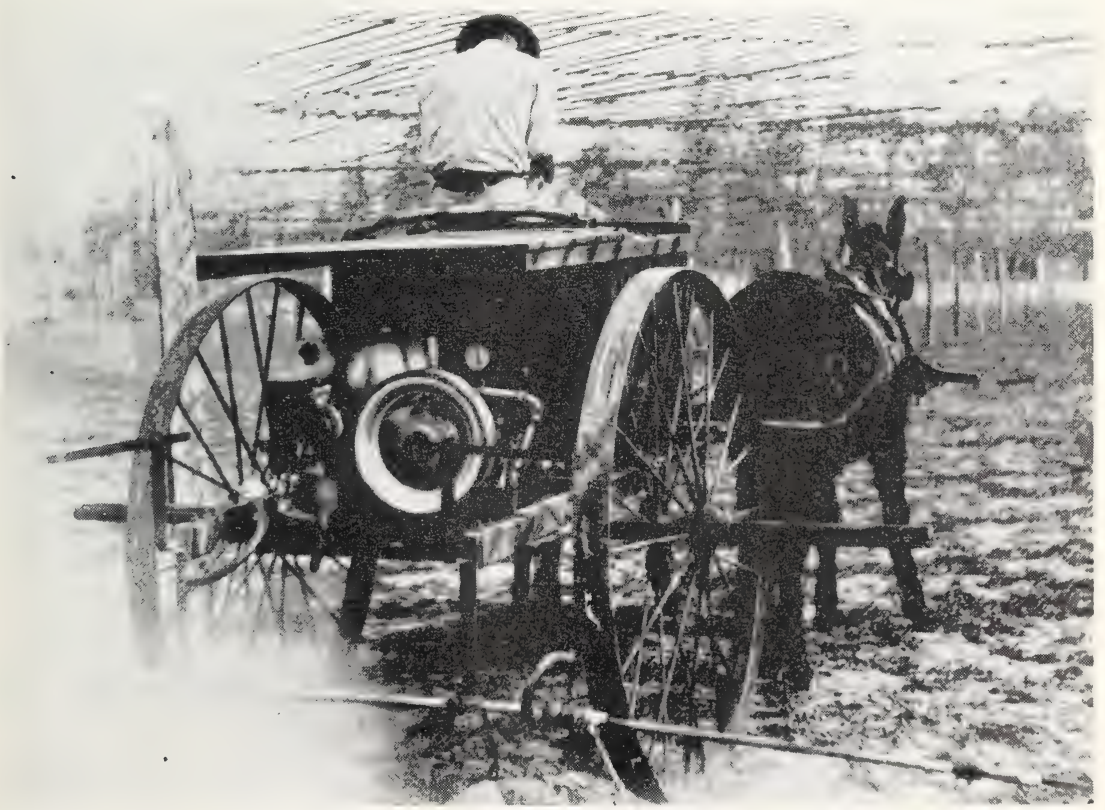

Figure 50.- Power sprayer used in tobacco thrips control. This method is much more efficient than the knapsack-pump method when large areas are to be treated. 
practicable with any available type of sprayer owing to the lack of working space and the attendant danger of breaking the foliage. In a few instances, however, spray applications have been made to high tobacco through long lines of hose attached to a power sprayer stationed outside the shade field.

To reduce thrips populations to the lowest possible point, spray applications should be begun soon after the plants are set in the field. In actual practice there is little incentive to begin spray operations unless and until the danger of a drought is impending in May. If the spray program is undertaken during the first week in May, a period of 2 to 3 weeks is then arailable for applications before the plants are tied up. As many thrips and the egg stage escape sprays,

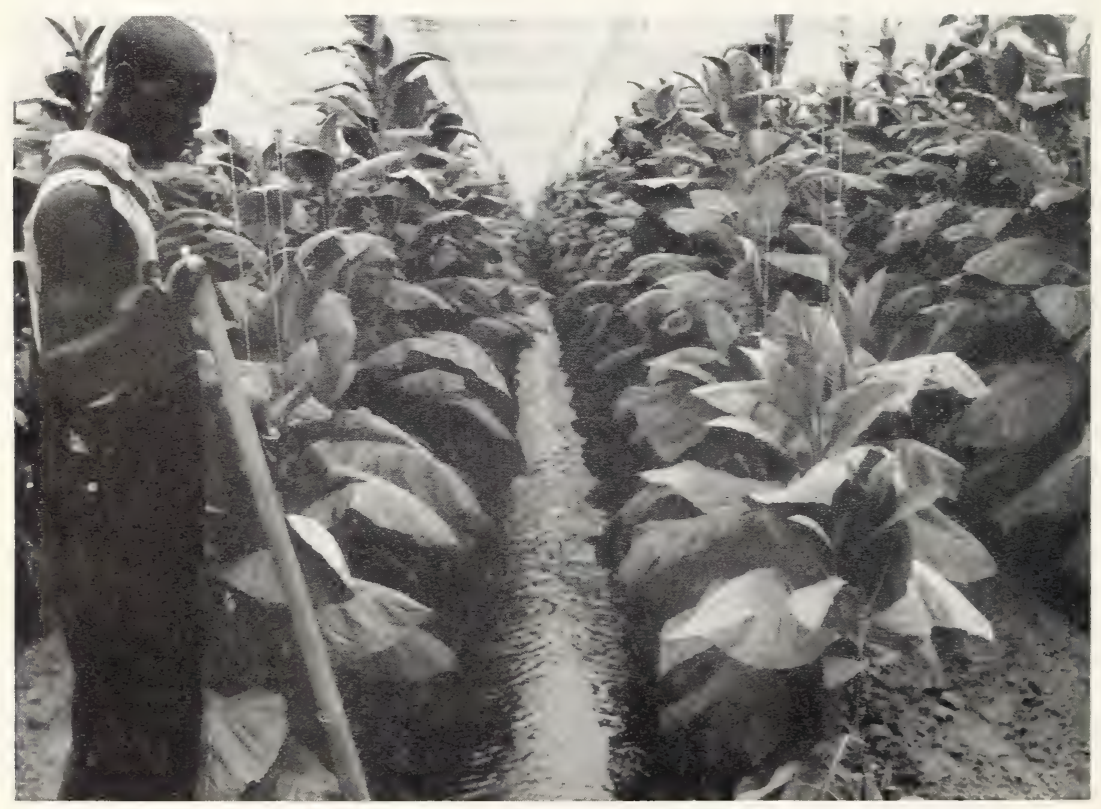

Figure 51.- Surface irrigation in a field of shade-grown tobacco. This practice hastens the maturity of the crop during periods of dry weather and thereby indirectly decreases the amount of thrips damage.

at least six applications have been found necessary to check heary infestations.

CULTLRAJ, CONTROL

As the tobacco thrips lives on many weeds and grasses, the elimination of these hosts by clean culture on tobacco land and adjacent areas prior to and during the tobacco-growing seasons will be of benefit.

Surface irrigation, as utilized by a considerable number of growers (fig. 51), does not appear to affect the thrips directly, but hastens the maturity of the crop during periods of dry weather and thereby indirectly decreases the amount of thrips damage.

\section{The Southern Green Stinkbug}

The southern green stinkbug (Nezara viridula (L.)) is a serious pest of some crops in this region, but it is usually of minor impor- 
tance on tobacco. The closely related brown stinkbug (Euschistus servus (Say)) also attacks tobacco to a limited extent.

The adults of the southern green stinkbug (fig. 52) are about onehalf inch long and are usually light green. The young are bluish with reddish markings. The eggs are deposited in clusters, usually on the under surfaces of leaves. The insect attacks nearly all truck crops, corn, sugarcane, citrus fruits, pecans, cowpeas, beggarweed, and a great variety of other wild and cultivated plants. The bugs obtain their food by puncturing the tissues of plants with their beaks and then extracting the plant juices. In the case of tobacco they usually feed on the midveins of the leaves from the under surfaces. If attacked severely, the leaves wither and turn brown.

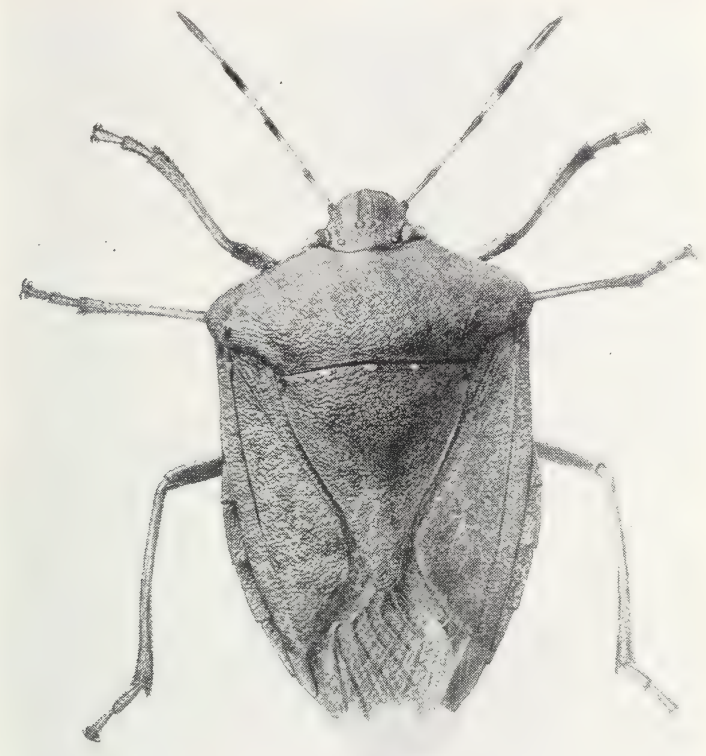

Figure 52.-Adult of the southern green stinkbug, about $\times 4$.

Attempts to control this pest on tobacco with insecticides have been unsuccessful. For the periodic attacks of this insect, hand-picking has proved effective in protecting the crop.

\section{WIREWORMS}

Wireworms attack newly set tobacco and when present in considerable numbers are very destructive to the young plants. In this region wireworm attacks are usually confined to only occasional plants, but in rare instances the insects destroy a considerable portion of the stand. Of the species of wireworms attacking tobacco in this region, the Gulf wireworm (Heteroderes laurentii (Guer.)) is commonly found, and two other species (Aeolus dorsalis (Say) and Monocrepidius sp.) are known. 
These insects are called wireworms because of their slenderness and uncommon hardness. When full-grown they are about one-half inch long and about one-eighth inch or less in diameter. They are usually yellowish with a red or brown head.

Wireworms tunnel the stems of young tobacco plants and may eat out the entire pith. They may feed on the plants for only a few days, or the attacks may continue for a period of several weeks.

To effective means of controlling wireworms on tobacco in this region have been found. Replanting with strong, rigorous plants as soon as the infested ones are discorered is the best known practice.

\section{The Suckfly}

The suckfly (Dicyphus minimus Uhl.) normally causes little or no damage to tobacco in this region. In some instances late crops of cigar-wrapper tobacco are reduced in quality as the result of sporadic outbreaks.

The suckfly is a very small, fragile, grayish insect and has relatively long legs and antennae. It is usually found on the under surfaces of the leaves, where it feeds on the plant juice. Hearily infested leaves become bleached or yellowish. The insect deposits small specks of excrement which add to the disfigurement of the leares.

The suckfly may appear in tobacco fields in June, but usually in very limited numbers. During the first part of July it sometimes occurs in sufficient abundance to cause apprehension. In the southern districts the harvesting of the shade-grown crop is usually nearing completion at this time.

\section{Climbing Cutworms}

Some of the cutworms frequently assume the climbing habit and feed on the foliage of high tobacco. The rariegated cutworm (Peridroma margaritosa (Haw.)) and the yellow-striped armyworm (Prodenia ornithogalli Guen.) occasionally cause considerable damage to the crop in this region. Both these cutworms range from gray to

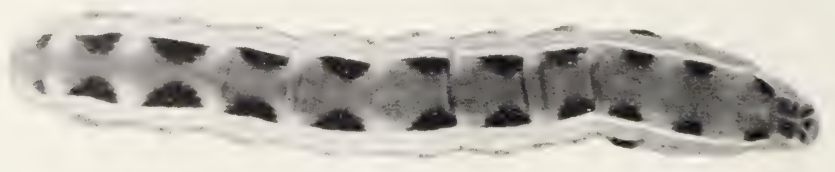

Figure 53.-Mature larra of the climbing cutworm Prodenia ornithogalli. About $\times 4$.

black, and the second species has conspicuous triangular black markings on the back (fig. 53). They feed on sun-grown and shade-grown tobacco, but are u-nally most abundant in the dense foliage of maturing shade crops. 
No entirely satisfactory methods for controlling climbing cutworms on tobacco are known. Light applications of paris green or applications of this arsenical mixed with lime, which are frequently used to control the hornworm, assist in reducing the numbers of these insects. The dosages of paris green that may be applied with a reasonable degree of safety to the crop, however, are only partially effective against the larger cutworms. When severe infestations occur, hand-picking of the larvae should be practiced.

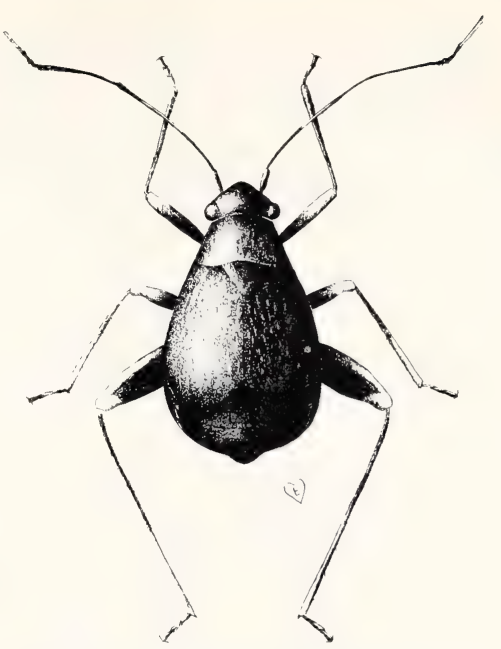

Figure 54.-The garden flea hopper : adult, wingless female, $\times 16$.

\section{The Garden Flea Hopper}

The garden flea hopper (Halticus citri (Ashm.)) is one of the tobacco pests of minor importance in this region. In some instances, however, appreciable injury

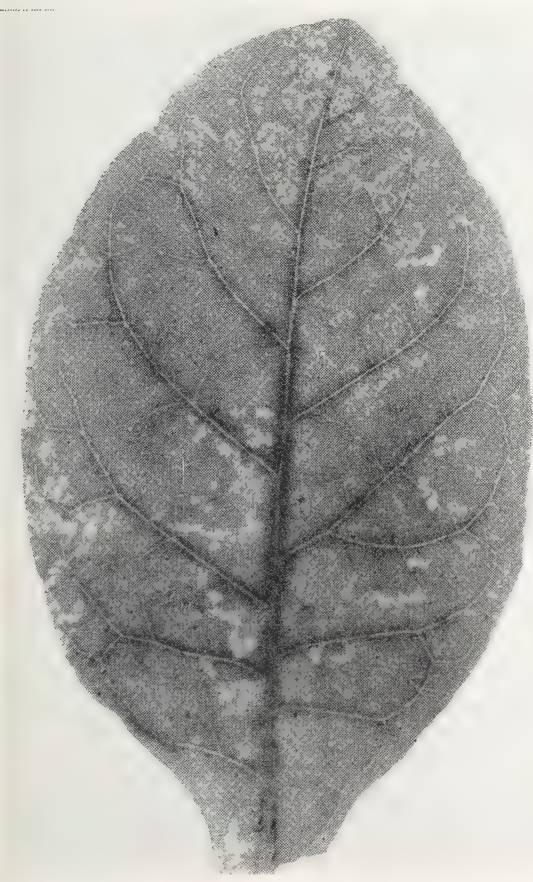

Figure 55.-Tobacco leaf disfigured by the garden flea hopper. may result from attack of this insect on the lower leaves of cigar-wrapper tobacco.

The adult wingless female (fig. 54) is often confused with the tobacco flea beetle, since both are of about the same size and both move in much the same manner. The garden flea hopper, however, is a sucking insect, whereas the tobacco flea beetle obtains its food by chewing off small portions of the leaves.

The flea hopper injures tobacco by inserting its sharppointed mouth parts into the leaf tissues and sucking out the juices. The affected areas (fig. $55)$ assume a whitened or bleached appearance. Frequently these small white spots coalesce when the feeding punctures are made close together. Small black deposits of excrement add to the disfigurement of the leaf. The white areas 
and the black specks remain on the leaves after they are cured, although the bleached areas are somewhat less noticeable after the leaves have passed through the sweating process.

The adult flea hoppers emerge from hibernation early in the spring and attack tobacco in the plant beds and in newly set fields. There appear to be several generations in this latitude. The insects are abundant in the late fall months but gradually disappear as cold weather approaches.

Flea hoppers feed upon a great variety of wild and cultivated plants. Truck crops and legumes are favored by this species.

Limited experiments in this region with insecticides for the control of this insect on tobacco have failed to yield any remedial measures of value.

It has been observed that the heavier infestations usually occur on tobacco crops that have been preceded on the ground by a heavy growth of vegetation or by truck crops late in the fall or in the early part of winter. For the prevention of flea hopper attacks it therefore appears advisable to keep tobacco land free of green vegetation during the preceding late-fall and winter months.

\section{The Potato Tuber Worm, or Tobacco Splitworm}

The potato tuber worm (Gnorimoschema operculella (Zell.)) is normally a pest of minor importance in the Georgia and Florida tobacco-producing region. When this insect attacks tobacco it is usually described as the "splitworm." Its occasional attacks on the lower leaves often arouse apprehension that the damage may continue through the entire crop.

The eggs from which the splitworm hatches are deposited on the tobacco leaves by a small gray moth. The young splitworms bore into the leaves and form the characteristic tunnels between the two leaf surfaces. They frequently tunnel the midrib or a vein in addition to the mining of the leaf tissue. When small tobacco plants are attacked the insect may tunnel into the stems and buds.

The full-grown larva is about three-fourths of an inch long, and is easily visible from both sides of the leaf. The body color varies from green to gray and frequently appears purplish.

Injury on tobacco in this region usually occurs on the lower leaves. Leaves that have been tunneled near the veins are frequently distorted (fig. 56). Considerable feeding by the insect renders them worthless. No control methods of definite value are known.

\section{OTHER INSECTS OCCASIONALLY FOUND FEEDING ON TOBACCO}

Several other species of insects feed to some extent on tobacco in this region with occasional damage. The more important ones will be discussed briefly.

The garden slug (Agriolimax agrestis (L.)) is not an insect, but should receive mention as it occasionally feeds on young tobacco plants in the beds and in the fields. These slugs, frequently called "snails," are grayish, slimy animals, usually about an inch in length. They injure tobacco under very damp, humid conditions. When conditions become normal the attacks usually cease. Hydrated or 
air-slaked lime has been reported as being very effective in controlling slugs. When they are attacking a plant bed the recommended dosage is 4 pounds of lime to 100 square yards. To protect newly set tobacco plants a dosage of from 5 to 10 pounds per acre is recommended. Late afternoon is believed to be the most suitable time for application.

The cabbage looper (Autographa brassicae (Riley)) frequently causes slight injury to sun-grown and shade-grown tobacco. The light greenish caterpillars feed on the leaves and cause injury somewhat similar to that produced by small hornworms. The application of remedies for the hornworm and flea beetle assists in controlling the looper.

The spotted cucumber beetle (Diabrotica duodecimpunctata (F.) ) feeds to a limited extent on tobacco in this region.

A large, dark-colored, hairy caterpillar (Callarctia phyllira (Drury) ) infrequently attacks young tobacco. The injury to the plants is very similar to that caused by cutworms.

Larvae of the crane flies (one or more species of Tipula) occasionally attack newly set tobacco plants in this region. These tough, black or grayish maggots feed on the stems and leaves. Feeding on the leaves is largely confined to those buried or partly buried at the time of transplanting and to the leaves which lie on the surface of the soil.

The greenhouse whitefly (Trialeurodes vaporariorum (Westw.)), the green peach aphid (Myzus persicae (Sulz.)), and the potato aphid

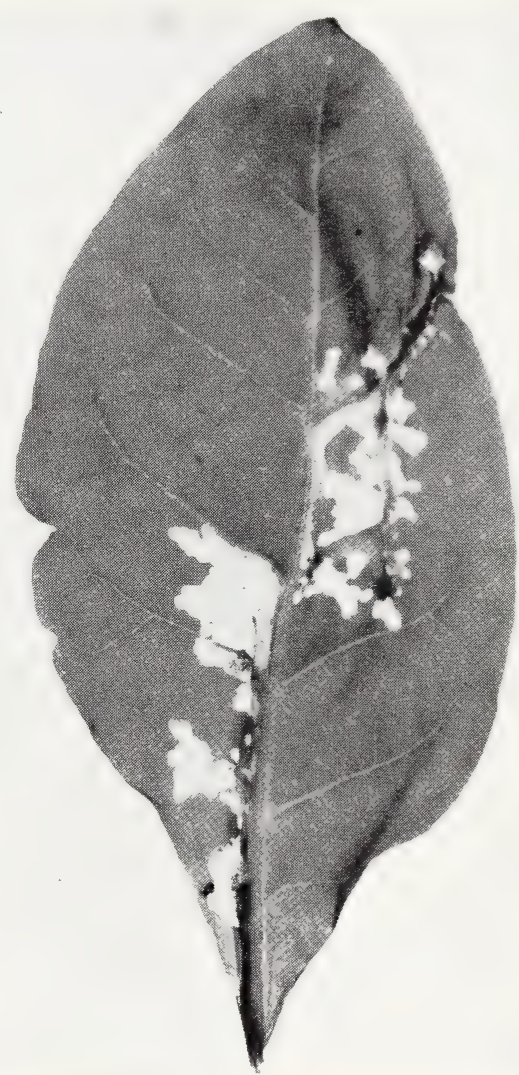

Figure 56.-Tobacco leaf showing the characteristic injury caused by the tobacco splitworm. (Macrosiphum (Illinoia) solanifolii (Ashm.)) have been found feeding on tobacco, but in very few instances have they been observed to have caused severe damage.

The field crickets Gryllus assimilis (F.) and Nemobius ambitiosus Scudd. are minor pests of plant beds and of newly set tobacco in this region. They are found most frequently under piles of old decaying stalks or trash. Poisoned bait applied for the control of budworms and cutworms also assists in the control of the crickets. 
The regetable weevil (Listroderes obliquns Klug), which occurred in harmful abundance in this region for the first time during the spring of 1937 , was found infesting a tobacco plant bed in considerable numbers. Larval feeding on the tender leares was extensive (fig. 57 ). and frequent instances were observed where the insects had entirely eaten awar the buds of the plants. The infestation increased during the first part of April and caused a considerable loss of plants in the portion of the bed attacked. Two fields of newly set tobacco were observed in which the larrae were feeding on the plants. In each instance the insects had apparently been carried on the plants from the infested bed to the fields. This is apparently the first recorded instance of the regetable weeril feeding on tobacco in the United

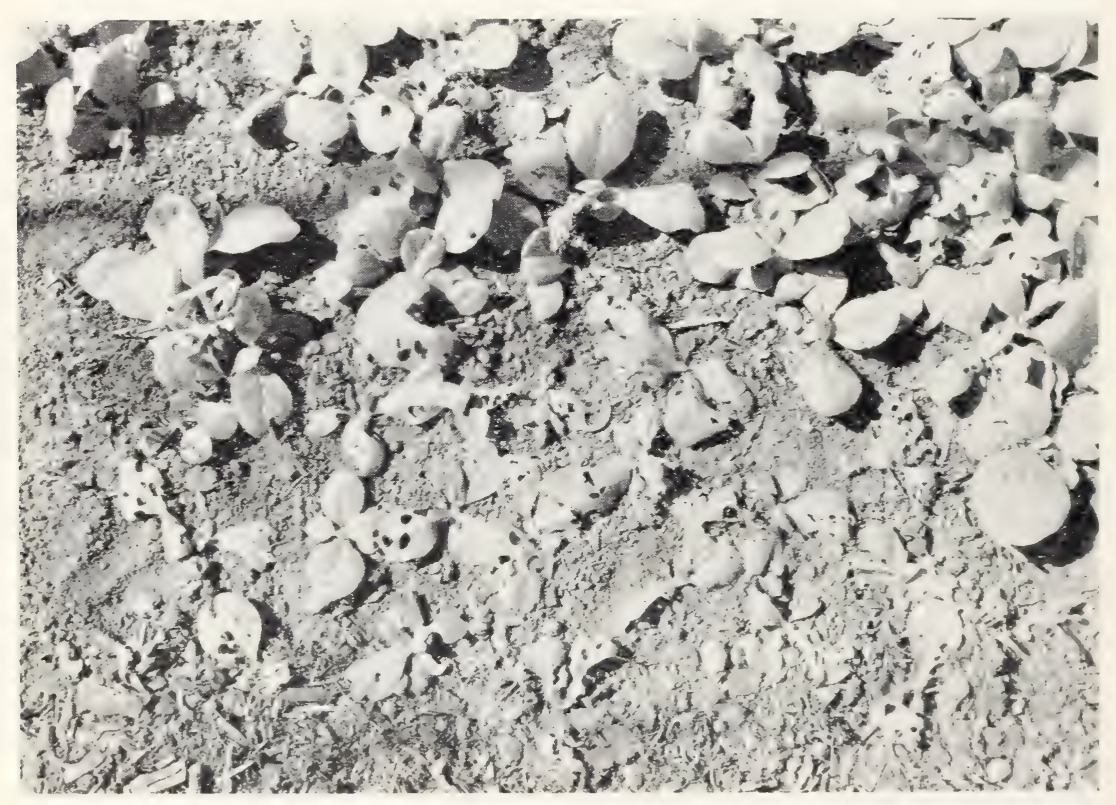

Figure 57.--Tobaceo seedlings, showing the injury caused by the larrae of the regetable reeril.

Stater. In 1938 and 1939 a considerable number of tobaceo plant bedwere infested with the weerils, and control measures were found nece-rary in sereral instances. Preliminary tests indicate that this insect may he controlled on plant beds by applications of lead arsenate.

The regetable weeril has become well established in a tobaccoproducing region for the firs time, and it may posibly become an economic pest of this crop.

\section{WHERE INSECTICIDES MAY BE OBTAINED}

The inesticides mentioned in this circular are unally avalable locally in drug. seed. hardware. and general stores. Information regarding the purchase of the materials can be obtained from the county agricultural agent. State agricultural experiment station. State 
igricultural college, State department of agriculture, or the Bureau of Entomology and Plant Quarantine, United States Department of Agriculture.

\section{SUMMARY}

Cigar types of tobacco-wrapper leaf, binder leaf, and filler leafgrown in the southeastern part of the United States are subject to the attack of several species of insects. While these insects attack all types of tobacco, the injury causes the greatest reduction in value to the wrapper type. The careful use of insect-preventive methods and the timely application of direct control remedies are necessary for the successful production of this type of leaf. Effective control measures must also be used in the production of the filler and binder types. Descriptions of the various types of insect injury, discussions of the available control measures, and facts concerning the habits of the injurious species are given in this circular.

The injurious insects which occur most frequently in the tobacco plant beds are mole crickets, flea beetles, and cutworms. Flea beetles may be controlled by the application of diluted cube- or derris-root powder containing 1 percent of rotenone. Injuries caused by mole crickets and cutworms may be prevented to a considerable extent by the application of poisoned-bran bait.

The three major insect pests of the crop in the field are the tobacco budworm, the tobacco hornworm, and the tobacco flea beetle.

The tobacco budworm may be controlled by means of a poisoned bait consisting of corn meal and lead arsenate in the proportions of 75 to 1 by weight, applied directly to the bud leaves. The number of applications necessary to protect the crop will vary with the tobacco types.

The most effectual means of controlling hornworms on wrapper tobacco grown under artificial shade is the careful maintenance of the cloth tops, side walls, and gateways of the shade structures. Tobacco grown in open fields does not have this means of protection. No entirely satisfactory hornworm poison is available at the present time, and efforts are being made to devise better measures for the direct control of this insect. Light applications of paris green or mixtures of this arsenical and hydrated lime usually exert fairly satisfactory control if used with extreme caution. The use of paris green, however, entails a considerable hazard of foliage burning. The hand-picking of larvae can frequently be practiced to advantage where the acreage is limited. The destruction of tobacco plants immediately after harvest and fall plowing are valuable means of reducing the numbers of this insect pest.

Flea beetle injury, which is most serious on wrapper tobacco, should be combated with preventive and with direct control measures. The most important preventive measure is the complete destruction of all tobacco stalks immediately after the crop is harvested. The most satisfactory direct control remedy for this insect consists in the application of a cube- or derris-root powder and sterilized tobacco dust mixture, containing 1 percent of rotenone.

Cutworms and grasshoppers may be controlled with poisoned-bran bait, the preparation and application of which are discussed in detail. Cultural control measures are also of value against these pests. 
The tobacco thrips causes injury to cigar-wrapper tobacco during abnormally dry growing seasons. No entirely satisfactory control remedy is available for this insect.

Other species of insects causing minor injuries to crgar tobacco in the region include the southern green stinkbug, wireworms, the suckfly, climbing cutworms, the garden flea hopper, and the tobacco splitworm.

Insects occasionally found feeding on tobacco hare receired brief mention. 




\section{ORGANIZATION OF THE UNITED STATES DEPARTMENT OF AGRI. CULTURE WHEN THIS PUBLICATION WAS EITHER FIRST PRINTED OR LAST REVISED}

Secretary of Agriculture

Onder Secretary

Assistant Secretary

Chief, Bureau of Agricultural Economics

Director of Agricultural Defense Relations

Director of Extension Work

Director of Finance

Director of Foreign Agricultural Relations

Director of Information.

Director of Personnel

Land Use Coordinator

Librarian

Solicitor

Chief, Office of Civilian Conservation Corps Activities.

Chief, Office of Plant and Operations

Administrator of Agricultural Marketing Administrator, Surplus Marketing Administration

Chief, Commodity Exchange Administration

Chief, Agricultural Marketing Service

Administrator of Agricultural Adjustment and

Conservation

Administrator, Agricultural Adjustment Administration.

Chief, Soil Conservation Service

Manager, Federal Crop Insurance Corporation

Chief, Sugar Division

Administrator of Agricultural Research

Chief, Bureau of Animal Industry.

Chief, Bureau of Agricultural Chemistry and Engineering.

Chief, Bureau of Dairy Industry

Chief, Bureau of Entomology and Plant Quarantine

Chief, Office of Experiment Stations

Chief, Bureau of Plant Industry

Chief, Bureau of Home Economics.

President, Commodity Credit Corporation

Administrator of Farm Security Administration

Governor of Farm Credit Administration.

Chief, Forest Service

Administrator, Rural Electrification Adminis-

tration

This bulletin is a contribution from

Bureau of Entomology and Plant Quarantine_ P. N. ANNAND, Chief.

Division of Truck Crop and Garden Insect

Investigations.
Claude R. Wickard.

PAUL H. APPLEBY.

Grover B. Hinl.

HOW ARD R. TOLLEY.

M. CLIFFORD TOWNSEND.

M. L. WILSON.

W. A. JUMP.

L. A. Whegrer.

Morse SALISBURY.

T. Roy ReID.

MILTON S. EISENHOWER.

RALPH R. SHAw.

Mastin G. White.

Fred MorrelL.

ARthur B. Thatcher.

ROY F. HENDRICKSON.

E. W. Gaumnitz.

JoSEPH M. MEHL.

Clarence W. Kitchen.

R. M. Evans.

Fred S. Wallace.

HUGH H. BEN NETT.

LeRoY K. SMIth.

JOSHUA BERNHARDT.

E. C. Auchter.

JOHN R. MOHLER.

HENRY G. KNIGHT.

OLtie E. Reit.

P. N. AnNand.

JAMES T. JARDINE.

E. C. AUCHTER.

LOUISE STANLEY.

J. B. Hutson.

C. B. Baldwin.

Albert G. Black.

Earle H. Clapp, Acting.

HARRY SLATTERT.
W. H. White, Principal Ento-

mologist, in Charge. 
